\title{
Environmental Assessment of Seafood Products through LCA
}

Final report of a Nordic Network project 



\section{Environmental Assessment of Seafood Products through LCA}

\section{Final report of a Nordic Network project}

Berit Mattsson and Friederike Ziegler (editors)

Other project participants: Helga Eyjolfsdottir, Mikkel Thrane, Harald Ellingsen, Staffan Larsson, Erling Larsen, Thomas Ohlsson, Frans Silvenius, Jyri Seppälä.

TemaNord 2004:546 


\section{Environmental Assessment of Seafood Products through LCA \\ - Final report of a Nordic Network project}

TemaNord 2004:546

(C) Nordic Council of Ministers, Copenhagen 2004

ISBN 92-893-1053-7

ISSN 0908-6692

Print: Ekspressen Tryk \& Kopicenter

Copies: 100

Printed on paper approved by the Nordic Environmental Labelling.

This publication may be purchased from any of the sales agents listed on the last page.

Nordic Council of Ministers

Store Strandstræde 18

DK-1255 Copenhagen K

Phone (+45) 33960200

Fax (+45) 33960202

\author{
Nordic Council
}

Store Strandstræde 18

DK-1255 Copenhagen K

Phone (+45) 33960400

Fax $\quad(+45) 33111870$

www.norden.org

\section{The Nordic Council of Ministers}

was established in 1971. It submits proposals on co-operation between the governments of the five Nordic countries to the Nordic Council, implements the Council's recommendations and reports on results, while directing the work carried out in the targeted areas. The Prime Ministers of the five Nordic countries assume overall responsibility for the co-operation measures, which are co-ordinated by the ministers for co-operation and the Nordic Co-operation committee. The composition of the Council of Ministers varies, depending on the nature of the issue to be treated.

\section{The Nordic Council}

was formed in 1952 to promote co-operation between the parliaments and governments of Denmark, Iceland, Norway and Sweden. Finland joined in 1955. At the sessions held by the Council, representatives from the Faroe Islands and Greenland form part of the Danish delegation, while Åland is represented on the Finnish delegation. The Council consists of 87 elected members - all of whom are members of parliament. The Nordic Council takes initiatives, acts in a consultative capacity and monitors co-operation measures. The Council operates via its institutions: the Plenary Assembly, the Presidium and standing committees. 


\section{Table of Contents}

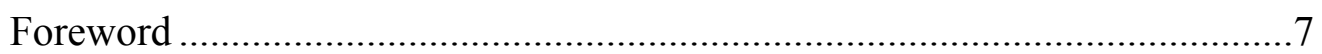

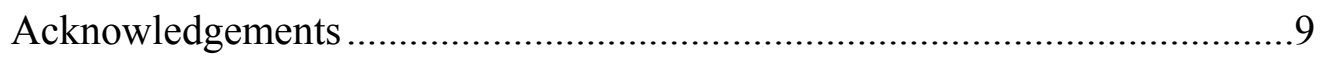

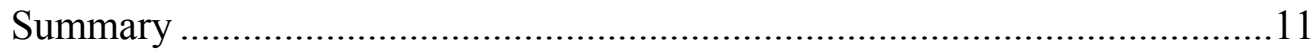

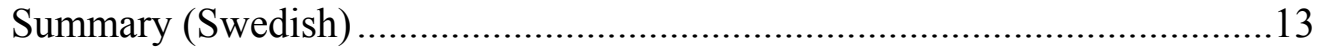

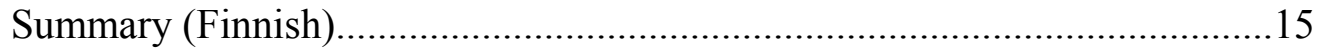

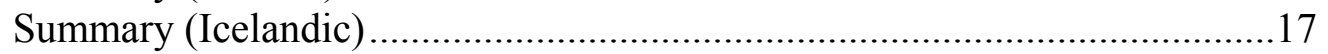

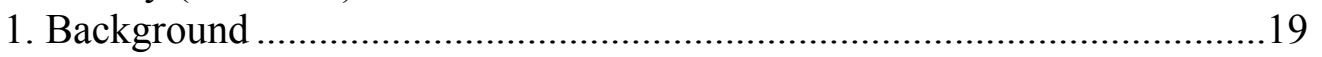

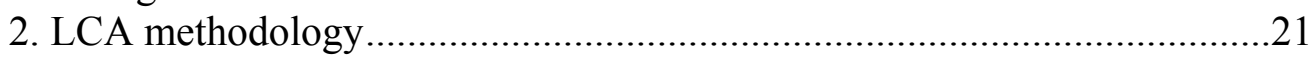

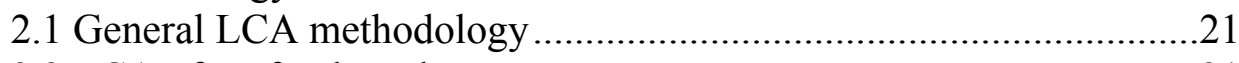

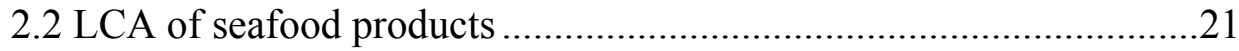

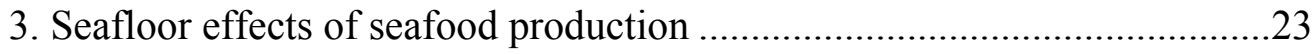

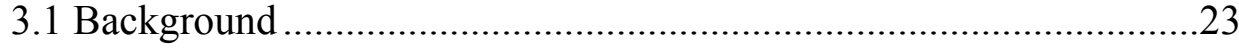

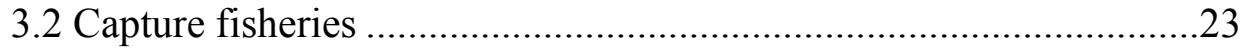

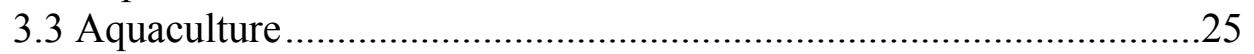

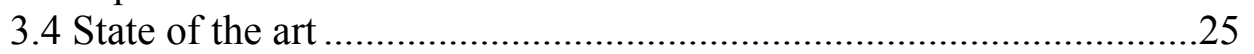

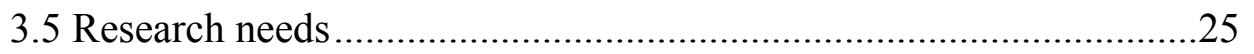

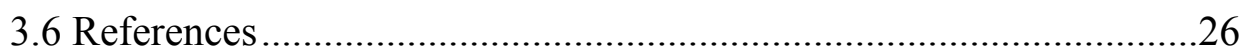

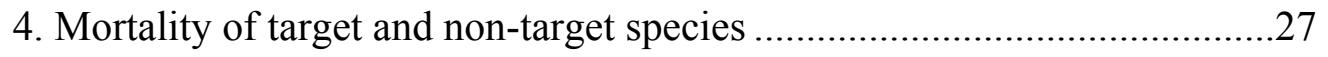

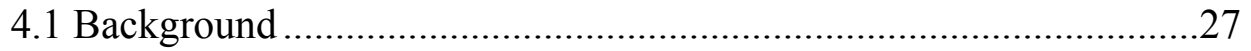

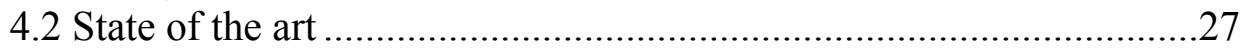

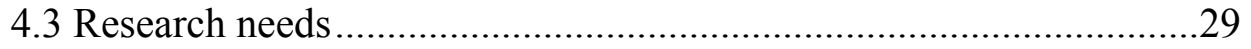

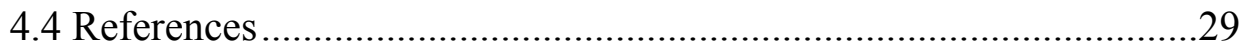

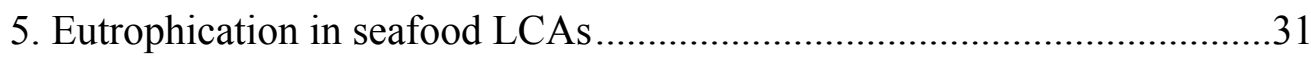

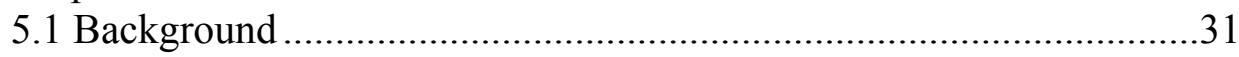

5.2 Importance of eutrophication for seafood production ...................... 31

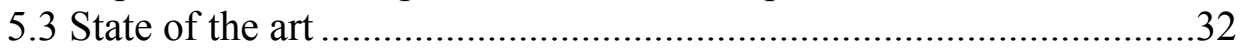

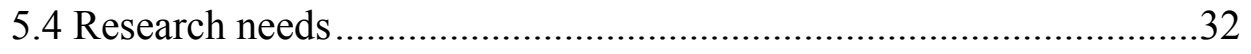

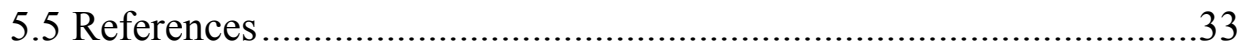

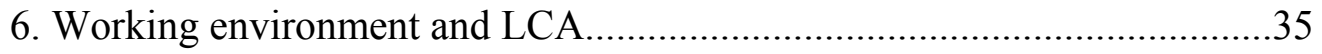

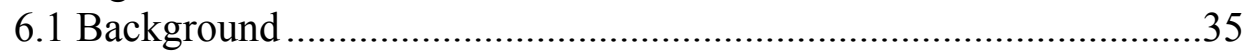

6.2 Can a better working environment be expected? .............................36

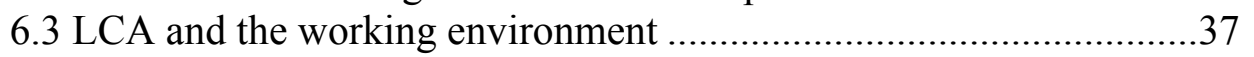

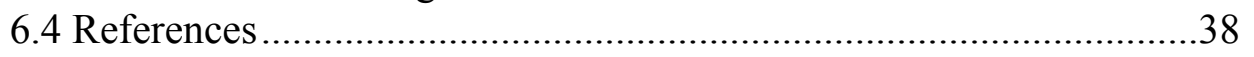

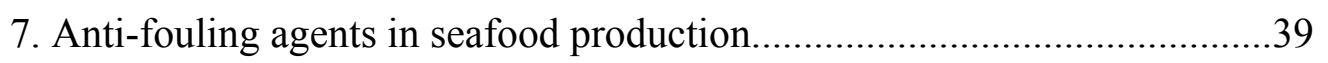

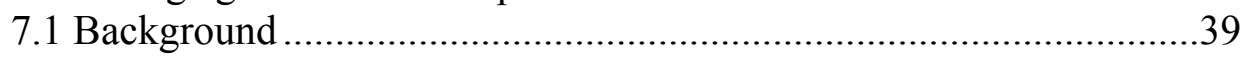

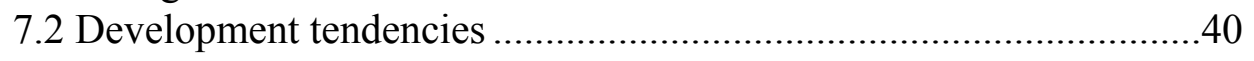

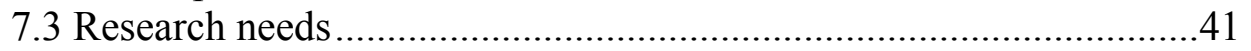

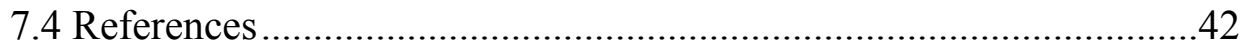

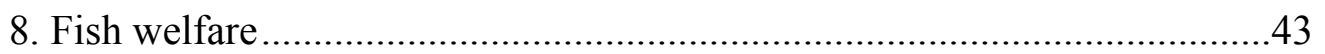

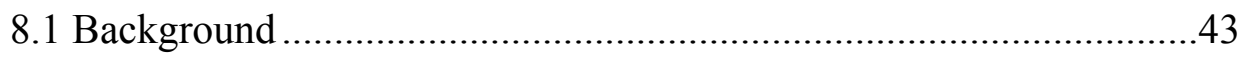

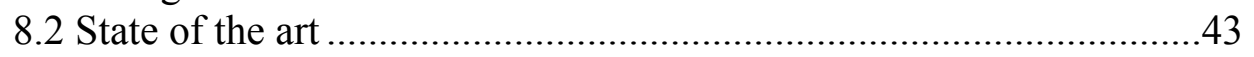

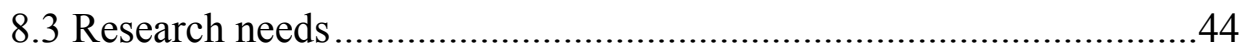

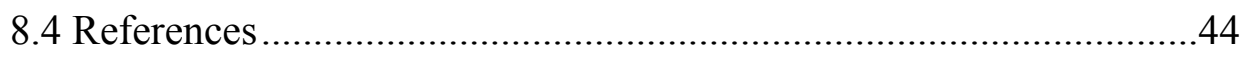




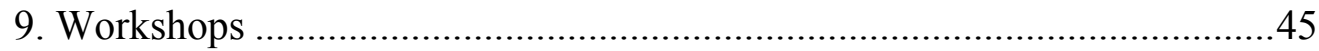

9.1 Workshop 1: Göteborg, February 26-27, 2001 ..................................45

9.2 Workshop 2: Hirtshals, August 15-17, 2001 ....................................47

9.3 Workshop 3: Trondheim, November 22-23, 2001 ............................57

9.4 Workshop 4: Reykjavík, March 21-22, 2002 .....................................62

9.5 Workshop 5: Roskilde, November 4-5, 2002 …………………….....72

10. Discussion and conclusions ....................................................................77

10.1 Main results of the network …………………………..................77

10.2 Application of results and benefits for the Nordic seafood sector...77

10.3 Conclusions regarding methodology …………………………….....78

10.4 Future outlook and need for further research....................................8

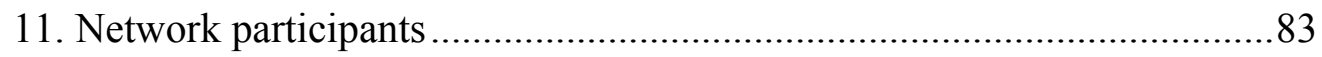




\section{Foreword}

The present report is a summary of a network project run during two years (2001-2002), mainly constituted by five workshops gathering researchers in the field of Life Cycle Assessment (LCA) and seafood to discuss and develop methodology for LCAs of seafood products. More detailed information about the different workshops can be found in the separate workshop reports. Project participants represented national projects in this field in Finland, Sweden, Denmark, Norway and Iceland. The project has resulted in exchange of research results between the national projects and has constituted a forum for discussion of methodological issues for the participants. Results of the network collaboration were disseminated to different stakeholders of the Nordic seafood sector in the final workshop. Methodological development has taken several important steps forward through this collaboration between single projects in the Nordic countries. These steps as well as the benefits of this development for the Nordic seafood sector are high-lighted in the present report.

List of separate workshop reports (can be obtained from the library at SIK, Ms. Helena Roshammar e-mail: hr@sik.se):

SIK Document 141

SIK Document 145 


\section{Acknowledgements}

We would like to thank the Nordic Strategy for Environment and Fisheries (MiFi) within the Nordic Council of Ministers for funding the network.We are especially grateful to Mr. Bo Storrank for patiently guiding us through the whole project from writing the application to the final report and everything in between. We would also like to thank all the participants, invited speakers and guests for taking the time to discuss these important questions. 


\section{Summary}

The project Network for environmental assessment of seafood products through LCA was started in 2001 with the objective to create a forum for Life Cycle Assessment (LCA) researchers from the Nordic countries in order to strengthen this research area and make application of this methodology to Nordic seafood products possible. The idea was to strengthen the market position of the Nordic seafood industry by communicating the results and implications of environmental assessments of their marine products and explain how these can be used to put environmental demands on suppliers, to make effective improvements in their own production or to communicate environmental performance of their products to customers and consumers. Therefore, communication of project results to stakeholders in the seafood product chain has been an important part of the project. Another important aspect of this work has been to discuss how environmental performance of seafood products can be assessed and how LCA studies can be utilized by seafood producers as well as fishery management organisations in order to achieve environmental improvements.

At the time when the project was initiated, LCA was established in other sectors but it had only recently been introduced in the fish sector. Nordic researchers were, and still are, pioneering this area of research and it has become more and more obvious that LCA methodology, which was developed for other types of products, must be adjusted to include vital environmental issues associated to fishery. This project can be seen as a first step to synchronize LCA methodology for seafood products.

The purpose of writing this report was to document presentations done at the workshops and some of the discussions and conclusions drawn by the project members. The report starts with a brief introduction to LCA methodology, continues with short reports about important environmental questions related to fishery and reports from the different workshops. Finally, a discussion of results, conclusions and a future outlook ends the report. Hopefully this will give a good picture of the status of LCA methodology for products coming from fishery and aquaculture. 


\section{Summary (Swedish)}

Projektet Network for environmental assessment of seafood products through LCA startades år 2001 med syftet att skapa ett forum för forskare inom Livscykelanalys (LCA) från de nordiska länderna för att utveckla detta område och göra en tillämpning av LCA-metodiken på fisk- och skaldjursprodukter möjlig. Meningen var att stärka den nordiska fisk- och skaldjursindustrin konkurrenskraft genom att delge den resultat och slutsatser från miljöanalyser av nordiska havsprodukter och förklara hur sådana analyser kan användas för att dels ställa miljökrav uppåt i produktionskedjan, dels göra effektiva miljöförbättringar i sin egen produktion samt kommunicera sina produkters miljöegenskaper till kunder och konsumenter. Därför har information om projektets resultat till olika aktörer i fisksektorn varit en viktig del av projektet. En annan viktig aspekt av detta arbete har varit att diskutera hur fisk- och skaldjursprodukters miljöegenskaper kan bedömas och hur LCAer kan användas av branschen och i fiskeriförvaltning för att åstadkomma miljöförbättringar.

Då projektet startades, var LCA redan en etablerad metod inom andra sektorer, men var fortfarande helt ny i fisksektorn. Nordiska forskare var, och är fortfarande, pionjärer inom detta område och det har blivit mer och mer tydligt att LCA-metodiken, som har utvecklats för andra typer av produkter, behöver anpassas för att kunna inkludera viktiga miljöfrågor kopplade till fiske. Det här projektet kan ses som ett första steg i att synkronisera LCA-metodik för fisk- och skaldjursprodukter.

Syftet med att skriva denna rapport var att dokumentera de presentationer som gjorts under projektets gång samt en del av de diskussioner och slutsatser som dragits av nätverksdeltagarna. Rapporten börjar med en kort introduktion till LCA metodik, fortsätter med beskrivningar av viktiga miljöfrågor kopplade till fiske och sammandrag från de fem möten som hållits inom ramen för projektet. Slutligen följer ett kapitel med diskussion av resultat, slutsatser och en blick in i framtiden. Förhoppningsvis skall detta ge en god bild av läget i utvecklingen av LCA-metodik för produkter som kommer från fiske och vattenbruk. 


\section{Summary (Finnish)}

Kalataloustuotteisiin liittyvien ympäristöasioiden arviointiverkosto LCA-menetelmälläprojekti alkoi vuonna 2001 tavoitteenaan luoda foorumi Pohjoismaiden elinkaariarviointi(LCA)asiantuntijoille alan tutkimuskentän vahvistamiseksi ja mahdollistamaan sellaisten sovellutusten kehittäminen, joilla LCA- metodologiaa voidaan käyttää pohjoismaisten kalataloustuotteiden tutkimiseen. Tarkoituksena oli vahvistaa pohjoismaisen kalatalousteollisuuden asemaa markkinoilla tiedottamalla alan tuotteita koskevien arviointien tuloksista ja vaikutuksista, selvittää mahdollisuuksia LCA-tutkimustulosten käyttöön esim. tarjolla olevien kalataloustuotteiden ympäristöohjauksessa, tehdä tehokkaita parannuksia alan tuotantoon tai välittää tuotteiden ympäristötietoja kuluttajalle tai asiakkaille. Niinpä, tutkimustuloksista tiedottaminen kalataloustuotteiden tuotantoketjun osakkaille on ollut tärkeä osa projektia. Muita tärkeitä aspekteja tässä työssä on ollut keskustella kalataloustuotteiden ympäristösuoritteiden arvioinnista ja kuinka kalataloustuottajat ja kalatalousviranomaiset pyrkimyksissään ympäristöasioita koskeviin parannuksiin voivat hyödyntää LCA-tutkimuksia

Projektin alkaessa oli LCA jo vakiintunut muille sektoreille, mutta sitä oltiin vasta juuri ottamassa käyttöön kalataloussektorilla. Pohjoismaiset tutkijat olivat, ja ovat edelleen, alan pioneereja ja koko ajan on tullut selvemmäksi, että LCA-menetelmä, joka on kehitetty muunlaisille tuotetyypeille, on sovitettava sisältämään kalastusta koskettavia ympäristöasioita. Tämä projekti voidaan nähdä ensimmäisenä askeleena LCAmetodologian synkronisoimiseksi kalataloustuotteille.

Tämä raportti kirjoitettiin projektiin liittyvien esitysten, projektiryhmän sisäisten keskustelujen ja niistä tehtyjen johtopäätösten dokumentoimiseksi. Raportti alkaa lyhyellä johdannolla LCA-metodologiasta ja jatkuu lyhyillä katsauksilla kalastukseen liittyvistä tärkeistä ympäristökysymyksistä ja raporteilla projektiin liittyvistä workshoptilaisuuksista. Raportti päättyy keskusteluun tuloksista, johtopäätöksistä ja tulevaisuudennäkymistä. Toivottavasti tämä antaa hyvän kuvan LCA-metodologian asemasta kalastuksessa ja vesiviljelyssä. 


\section{Summary (Icelandic)}

Netverkefnið Notkun vistferilgreiningar við mat á umhverfisáhrifum sjávarafurða hófst árið 2001 og hafði pað markmið að styrkja markaðsstöðu sjávarútvegs og fiskvinnslu á Norðurlöndum með pví að miðla niðurstöðum úr rannsóknum sem gerðar hafa verið á umhverfisáhrifum sjávarafurða.

Markmið verkefnisins var að skapa vettvang fyrir vísindafólk á sviði vistferilgreiningar (Life Cycle Assessment, LCA) á Norðurlöndum til að efla rannsóknir á pessu sviði og til að aðlaga pessa aðferðarfræði norrænum sjávarafurðum. Miðlun rannsóknarniðurstaðna til hagsmunaaðila í sjávarútvegi hefur p.a.l. verið mikilvægur páttur í verkefninu. Pegar verkefnið hófst var vistferilgreining pegar vel pekkt í mörgum framleiðslugreinum en var nýlunda í sjávarútvegi. Vísindafólk á Norðurlöndum hefur verið í fararbroddi á pessu sviði og pað kemur sífellt betur í ljós að vistferilgreiningu, sem upphaflega var próuð til að meta aðrar vörur, parf að aðlaga til að hægt sé að meta mikilvæga umhverfispætti sem tengjast fiskveiðum og vinnslu á fiski.

Hægt er að líta á verkefnið sem fyrsta skrefið í átt til pess laga vistferilgreiningu að sjávarafurðum. Annar mikilvægur páttur pessa verkefnis er hvernig hægt er að meta umhverfisáhrif og hvernig framleiðendur sjávarafurða og pær stofnanir sem bera ábyrgð á stjórn fiskveiða geta notað vistferilgreiningu til að draga úr umhverfisáhrifum.

Tilgangur pessarar skýrslu var að taka saman erindi sem flutt hafa verið á vinnufundum og einnig að halda til haga ýmsum peim umræðum sem farið hafa fram og peim niðurstöðum sem pátttakendur í verkefninu hafa komist að. Skýrslan hefst á stuttri kynningu á aðferðarfræði vistferilgreiningar, síðan eru stuttar samantektir á mikilvægum umhverfispáttum sem skipta máli við mat á umhverfisáhrifum fiskveiða og pá greinargerðir frá hinum ýmsu vinnufundum. Skýrslan endar síðan á umfjöllun um niðurstöður, ályktunum og framtíðarhorfum. Vonast er til að skýrslan gefi góða mynd af notkun vistferilgreiningar sem aðferðafræði við mat á umhverfisáhrifum sjávarafurða og eldifisks. 


\section{Background}

In recent years awareness about the production limitations of our seas has increased both in fisheries managing authorities, among consumers and in the research community. This growing awareness has led to an increasing demand both for environmental information about seafood production as well as for eco-labelled seafood products. However, methods and data for assessment of environmental impact related to fishing activities have been lacking.

In five Nordic countries, national projects with the goal of assessing the environmental impact of seafood products with a life-cycle perspective were started in 1998-2000. Nordic researchers were, and still are, pioneering this area of research. The researchers involved in these projects identified the benefits that could be made from exchanging experiences, sharing results, data and together developing methodology for environmental assessment of seafood products further. Collaboration would speed up development and make a more stream-lined use of LCA by the Nordic seafood sector closer. Therefore, the project Network for environmental assessment of seafood products through LCA was started in 2001 with the objective: "To strengthen the market position of the Nordic fish industry by communicating the results and implications of projects on environmental assessment of their fish products."

Communication between the stakeholders in the fish product chain has been an important part of the project. The intent was also to create a forum for Life Cycle Assessment (LCA) researchers from the Nordic countries in order to strengthen this research area. At the time when the project was initiated, LCA was established in other food production systems but it had only recently been introduced into the seafood sector. The project can be seen as a first step to synchronize LCA methodology for seafood products. Another important aspect of this work is how environmental performance can be assessed and how LCA studies can be utilized by fish producers as well as fishery management organisations in order to achieve environmental improvements.

The purpose of writing this report is to document presentations done at the workshops and some of the discussions and conclusions drawn by the project members. It includes information from many different authors and we have deliberately not tried to change them, meaning that different parts of the report are written in different styles. Some of the presentation summaries are e.g. written by the presenters themselves and some are written by the network participants, often the workshop organisers. The reports starts with a brief introduction to LCA methodology, continues with short reports about important environmental questions related to fish products and reports from the different workshops. Discussion and conclusions follow and the report is ended by a future outlook. Hopefully, this will give a good picture of the status of LCA methodology development for seafood products originating in fisheries or aquaculture. 


\section{LCA methodology}

\subsection{General LCA methodology}

Life Cycle Assessment is a method for assessment of the environmental impact of a product through its entire life cycle. The performance of an LCA is divided into four main parts: Goal and scope definition, Inventory analysis, Impact assessment and Interpretation of results. In the goal and scope definition the system to be studied and the purpose of the study is defined. System boundaries are chosen, preferably reflecting the boundary between the natural and the technical system. The inventory analysis consists of gathering of data concerning the resource use, energy consumption, emissions and products resulting from each activity in the product chain. The first results of an LCA is a matrix of inventory results, where the calculated values for each phase of the life cycle and the total values are presented. In order to simplify this table and to get an idea of what kind of environmental impact the emissions cause, characterisation methods are used to weight together all emissions causing e.g. global warming, acidification, toxicity, eutrophication, photochemical ozone formation and stratospheric ozone depletion. Characterisation together with qualitative assessment of types of environmental impact that cannot be characterised is called impact assessment. After the impact assessment is completed, the interpretation of results and identification of key issues and improvement options follow to finalise the LCA.

\subsection{LCA of seafood products}

LCA is basically a material flow analysis but important environmental impacts of fishery are not material flows in that sense. For instance the use of trawlers may damage the sea bottom in a way that is similar to soil tillage in agriculture. Another example is the impact on the stocks of the target species as well as on by-catch species. These issues were addressed at a workshop in Hirtshals in 2001 where it was decided that these issues should be addressed further so the work of writing short reports on these issues was assigned to the project partners and the results are presented below. They each present an area were LCA methodology needs to be developed to suit seafood products. These short reports were presented and discussed at the final workshop in Roskilde. The reports on seafloor effects, by-catches etc. include information presented at workshops as well as information from other sources. These reports can be seen as the essence of the issues discussed throughout the project. 


\section{Seafloor effects of seafood production}

Friederike Ziegler

The Swedish Institute for Food and Biotechnology

P.O. Box 5401, SE-402 29 Göteborg, Sweden.

Ph. 46313355600 , e-mail: fz@sik.se

\subsection{Background}

Seafloor effects are an important type of environmental impact connected to seafood production (Jennings 1998, Kaiser 2000, Lindeboom 1998, Ziegler 2002). The issue is of interest to fisheries managers, responsible for the long-term sustainability and to the seafood consumers who want to choose alternatives with less seafloor-impact when purchasing seafood. Seafood companies also become increasingly interested in minimising seafloor damage both to improve the environmental image of their products and in order to ensure long-term productivity of the habitats where the species they use live and spawn. They also have an interest in increasing knowledge about these issues in order to avoid frequent use of the precautionary principle putting restrictions on fisheries where they might not be necessary. For all these reasons, when doing a seafood LCA, the seafloor impact should not be left out. The seafloor impact category can be compared to terrestrial land use sometimes assessed in LCAs for land-based activities.

\subsection{Capture fisheries}

Seafloor effects of capture fisheries mainly stems from the use of towed fishing gear such as trawls and dredges which are dragged across the seafloor (Fig.1) to obtain species like cod, haddock, plaice, crayfish and scallops living close to or on the seafloor. Other organisms living on or in the sediment can be directly crushed by the gear or they can be exposed to predators when the sediment is turned around by e.g. a trawl or the trawl doors (Fig.1). Fragile benthic animals feeding by filtrating the seawater such as corals, sponges and bivalves are very sensible to fishing disturbance and disappear from fished areas even at low fishing pressure (Anon. 2000, Bergman 2000, Hall 1999, Olsson 1996). Scavenger species such as some fish, crab, starfish and brittlestars can increase at fished sites, benefiting from the increased abundance of food (damaged or dead benthic animals) (Demestre 2000, Lindeboom 1998, Ramsay 1998). However, the extra food is often consumed quickly. The size of the impacted area depends on the width of the gear and the towing speed of the vessel. The effects of this activity depends both on the type of habitat impacted, on the frequency of the impact and of the characteristics of the gear (e.g. whether it digs into the seabed or not). Fixed 
gears like traps, gillnets and long-lines, mainly affect the seafloor during setting and hauling.

Fig. 1 Otter trawl with trawl boards during fishing

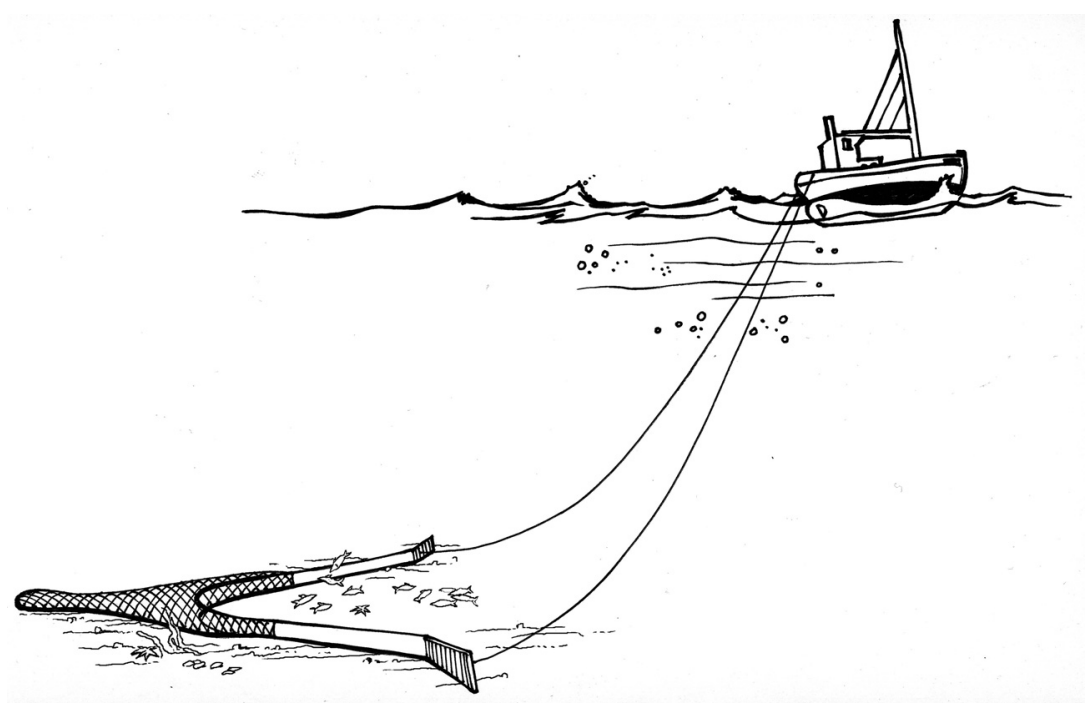




\subsection{Aquaculture}

The seafloor effect of aquaculture is related to the localisation of the farming facility and the treatment of the nutrient-rich wastewater. If it is a sea-based facility, localised in an area with insufficient water exchange in relation to the size of the farm, excretion products and excess feed will accumulate on the seafloor beneath the farm. This can lead to local eutrophication effects in the immediate surroundings of the farming facility, which is one of the most important types of environmental impact of aquaculture (D'Souza 2001, Wurts 2000). Eutrophication leads to increased growth of biomass of algae, phytoplankton and other marine species. The increased biomass eventually dies and accumulates on the seafloor where oxygen is used for decomposition. Oxygen deficiency in the seafloor-near water layers leads to replacement of aerobic benthic bacterial communities by anaerobic communities which are based on reduction of nitrogen or sulphur for energy supply. Changes in the benthic bacterial community can also be caused by antibacterial substances leaking out from the aquaculture facility. For land-based units, wastewater treatment, which can prevent these local eutrophication effects, is easier as the wastewater is led out through one tube.

\subsection{State of the art}

The problem with assessing the seafloor impact of fishing activities is the general lack of data on the spatial distribution of fishing effort with different gears. Sometimes it is reported, but at a scale too coarse to draw conclusions about effects in specific habitats. When estimations have been made, it has often been in the form of 'total area trawled', i.e. total fishing effort multiplied by an impact index per fishing hour depending on the size of the gear and the speed of the vessel during towing. However, such measures are as precise as accounting for the total area impacted by cars on land as the size of cars multiplied by their speed and total hours driven. In reality, fishing is highly concentrated to certain areas with a suitable seabed, distance from harbours and lack of physical obstacles like wrecks, oil riggs and rocky areas. Therefore, it would be more realistic to look at the real distribution of fishing effort in different types of marine habitats to assess the intensity in the fishing disturbance (Nilsson \& Ziegler, unpubl.). To my knowledge, the seafloor impact has only been included in one seafood LCA in terms of total area trawled of high- and low-oxygen-seafloor (Ziegler et al. 2002).

\subsection{Research needs}

The limited knowledge about the dynamics of benthic ecosystems in general and the distribution of fishing effort in these habitats (as well as their response to it) in particular are the most evident data gaps to fill in order to be able to predict the seafloor impact of a certain fishing or aquaculture activity in the future (predictive habitat management). Such predictions are necessary to be able to include seafloor impact in seafood LCAs without making rigorous research also about the seafloor impact of the specific seafood production. 


\subsection{References}

Anon. 2000. Report of the working group on ecosystem effects of fishing activities ICES Advisory Committee on the Marine Environment (ACME). 93 pp.

Bergman, M.J.N., van Santbrink, J.W. 2000. Fishing mortality of populations of megafauna in sandy sediments, Chapter 4 in: Effect of fishing on non-target species and habitats Edited by Kaiser, M.J., de Groot, S.J. Blackwell Science, pp. 49-68.

Demestre, M., Sánchez. P., Kaiser, M.J. 2000. The behavioural response of benthic scavengers to ottertrawling disturbance in the Mediterranean, Chapter 8 in: Effect of fishing on non-target species and habitats Edited by Kaiser, M.J., de Groot, S.J. Blackwell Science, pp. 121-129.

D'Souza, J., Colvalkar, N. 2001. Shrimp farming and its impact on the environment. Journal of environment and pollution 8: 19-34.

Hall, S.J. 1999. The effects of fishing on marine ecosystems and communities. Blackwell Science.

Jennings, S., Kaiser, M.J. 1998. The effects of fishing on marine ecosystems In Advances in Marine Biology Edited by Academic Press, pp. 201-352.

Kaiser, M.J., de Groot, S.J. 2000. Effects of fishing on non-target species and habitats. Biological, conservation and socio-economic issues. Blackwell Science.

Lindeboom, H.J., de Groot, S.J. 1998. IMPACT II The effects of different types of fisheries on the North Sea and Irish Sea benthic ecosystems EU project report. Netherlands Institute for Sea Research (NIOZ). 404 pp.

Olsson, I., Nellbring, S. 1996. Fiske och vattenbruk- ekologiska effekter (Fishery and aquacultureEcological effects, in Swedish) Naturvårdsverket. 181 pp.

Ramsay, K., Kaiser, M.J., Hughes, R.N. 1998. Responses of benthic scavengers to fishing disturbance by towed gears in different habitats. Journal of experimental marine biology and ecology 224: 7389.

Wurts, W.A. 2000. Sustainable aquaculture in the twenty-first century Reviews in Fisheries Science 8: 141-150.

Ziegler, F., Nilsson, P., Mattsson, B., Walther, Y. 2002. Life Cycle Assessment of frozen cod fillets including fishery-specific environmental impacts (in press in: Int J LCA; online DOI: http://dx.doi.org/10.1065/lca2002.08.094)) 


\section{Mortality of target and non-target species}

Helga R. Eyjólfsdóttir, The Icelandic Fisheries Laboratories, Skúlagata 4, 101 Reykjavik. Phone: 00354 5620240, e-mail: helgar@rf.is

\subsection{Background}

Industry fishing affects the marine ecosystem and therefore the mortality of both target species and non-target species (Ziegler, 2001, Kaiser, 2000, FAO, 1994). A fishery normally has one or several target species, which lead to both by-catch and discards. That is a well known problem in every fishing management system. Scientists have realised the importance of studying how much industrial fishing contributes to both stock depletion and disturbance of the marine ecosystem in general. For some species, fisheries management regulates the fishing mortality by TAC (Total Allowable Catch), which is based on research of Marine Research Institutes throughout the world which make estimates of stock sizes for important species. In the past, fisheries biologists have concentrated on studying the direct effects of fishing on stocks of target species and understanding the processes of recruitment. There is now a growing appreciation of the ecological implications of the wider effects of fishing activities on marine organisms and their habitats (Kaiser, 2000).

\subsection{State of the art}

The definition of the terms by-catch and discard varies between research studies, which makes it difficult to compare studies in this field (FAO, 1994). A workshop held in 1992 to sort out this problem resulted in definitions of the terms for by-catch and discards (McCaughran, 1992). In Fig. 2 a common view on the terms target catch, bycatch and discard is given. 
Fig. 2 A common way to define target catch, by-catch and discard.

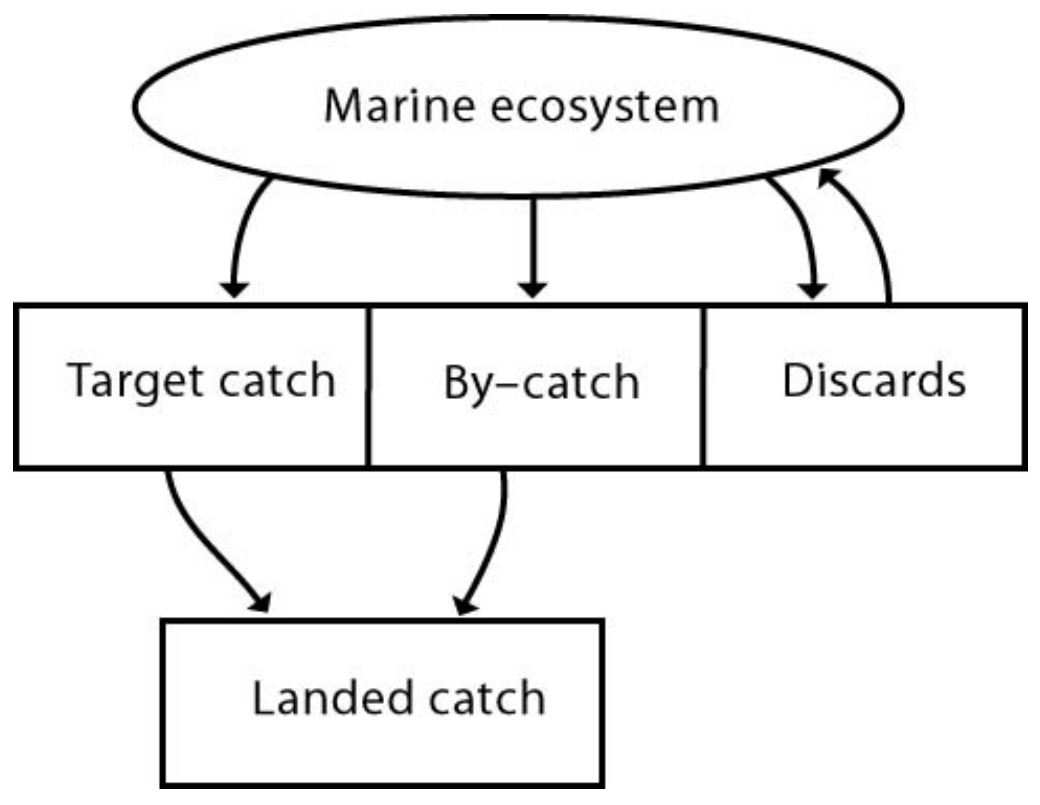

Environmental issues receive more and more attention when estimating the impact of fisheries in general. The focus is not just on over-exploitation of the world's fish resources, but also on knock-on effects caused by removal of the target species for other parts of the ecosystem (Hall, 1999). Attempts to correlate time-series trends in the abundance of non-target species with fishing disturbance trends have been inconclusive and a better approach towards determining fishing effects on non-target species lies through the development of underlying theory / hypotheses which would enable diversity changes to be more strongly related to changes in fisheries exploitation patterns (Greenstreet, 2000).

Hjerne (2001) stated that fish and fishery influence nutrient dynamics in marine systems and should be considered in ecosystem-oriented fisheries management. He stated at the Hirtshals network meeting (see pp. 42-51 and SIK document 145) that fishery actually increases the mortality of pelagic fish with $100 \%$ and $500 \%$ for predatory fish. This huge and continuous environmental impact is accepted, because fishery provides us with a lot of benefits and because we are not aware of the ecological effects under the sea surface.

As with population dynamics of fish populations, natural mortality of small cetaceans includes death due to disease, starvation and senescence. Other reasons for mortality include death due to collisions with vessels, excessive contaminant load or exposure to toxic substances and direct takes (ICES, 2001). Biomasses of non-target species are difficult to estimate accurately. Without such estimates it is not possible to quantify and evaluate impact in terms of by-catch mortality (ICES, 2002). 


\subsection{Research needs}

Scientists working with LCA of seafood consider this issue (discards, by-catch, mortality of non-target and target species) to be important when estimating the environmental impact of fisheries (SIK document 145). The question is, what kind of indicator could be used? References that touch this subject focus on the conditions of the stock, the stock size and research regarding how to estimate the TAC.

Monitoring programmes that provide adequate coverage of fisheries over large areas and for multiple years is a way to obtain information on by-catch by gear type, season and over years (ICES 2001). The limited knowledge about the dynamic between the marine ecosystem and the effect of fishing on target and non-target species is an important data gap to fill.

\subsection{References}

Anon. 2000. Report of the working group on eco system effects of fishing activities ICES Advisory Committee on the Marine Environment (ACME). 93 pp.

FAO 1992. Alverson, D.L. et.al 1994. A global assessment of fisheries bycatch and discards. FAO fisheries technical paper 339 .

Greenstreet, S.P.R. and Rogers, S.I. (2000). Effects of fishing on non-target fish species. Chapter 14 in: Effects of fishing on non-target species and habitats. Edited by Kaiser, M.J., and de Groot, S.J.Blackwell Science, pp 217-234.

Hall, S.J. 1999. The effects of fishing on marine eco systems and communities. Blackwell Science.

Kaiser, M.J., de Groot, S.J. 2000. Effects of fishing on non-target species and habitats. Biological, conservation and socio-economic issues. Blackwell Science.

Hjerne, O. and Hansson 2002. The role of fish and fisheries in Baltic Sea nutrient dynamics. In Oceanogr., 47(4) 1023-1032, The American Society of Limnology and oceanography.

ICES (2001). Report of the ICES advisory committee on eco system. No. 249 Copenhagen, 27-31 August.

ICES (2002). Report of the working group on eco systems effects of fishing activities. ICES CM 2002 / ACE:03.

Mc Caughran, D.A. 1992. Standardise nomenclature and methods of defining bycatch levels and implications. Proceedings of the National Industry Bycatch Workshop (R.W. Schoning, R.W. Jacobsen, D.L., Alverson, T.G., Gentle, \& J. Auyong, eds), pp. 200-201. Natural resources consultance, Seattle, Washington.

Ziegler, F., Nilsson, P., Mattsson, B., Walther, Y. 2002. Life Cycle Assessment of frozen cod fillets including fishery-specific environmental impacts (in press in: Int J LCA; online DOI: http://dx.doi.org/10.1065/lca2002.08.094).

SIK Document 145. Nordic network on LCA of fish, North Sea Centre, Hirtshals, Denmark, August 1517, 2001. 


\section{Eutrophication in seafood LCAs}

Frans Silvenius ${ }^{1}$ and Jyri Seppälä ${ }^{2}$

${ }^{1}$ Finnish Game and Fisheries Research Institute, P.O.Box 6. 00721 Helsinki, Finland, Phone 35820 521386, e-mail: frans.silvenius@rktl.fi

${ }^{2}$ Finnish Environment Institute, P.O.Box 140, 00251 Helsinki, Finland, Phone 3589 40300322, e-mail: jyri.seppala@ymparisto.fi

\subsection{Background}

In practice, impact assessment components of LCAs concentrate on global impact categories (climate change and ozone depletion) and on regional impact categories (e.g. acidification, tropospheric ozone formation, eutrophication). However, eutrophication is problematic among the other regional impact categories because the magnitude of effects depends on the environmental conditions. To be exact a distinction between terrestrial and aquatic eutrophication must be made (see e.g. Potting et al. 2002). In this paper, eutrophication is presented from the point of view of aquatic ecosystems.

Aquatic eutrophication can be defined as nutrient enrichment of the aquatic environment (Kristensen and Hansen 1994). Furthermore, the nutrient enrichment can cause undesirable effects on water quality and on the populations of aquatic organisms. The effects of eutrophication are generally more apparent in shallow, static or slowly moving waters. The scale of effects can cover distances from about one kilometre to some hundreds of kilometres. For this reason, aquatic eutrophication can be regarded as a regional/local impact category. Moreover, aquatic eutrophication is a difficult impact category because it is caused by both air and water emissions.

\subsection{Importance of eutrophication for seafood production}

Why is eutrophication an important impact category for seafood production? Firstly, aquatic eutrophication is a widespread problem in inland and coastal waters around the world and therefore it should be one of the impact categories to be considered in LCA.

Secondly, fish farming can cause aquatic eutrophication by releasing phosphorus and nitrogen to the water body. In sensitive water ecosystems such as shallow Finnish lakes these emissions can cause strong local eutrophication effects. For example, the LCA study of Finnish cultivated rainbow trout (Seppälä et al. 2001) showed that when comparing the emissions originating from rainbow trout production taking into account all life cycle stages, eutrophying discharges appeared to be environmentally the most significant emissions. The cultivation stage causes by far the most of the total phosphorus and nitrogen emissions originating from the whole product chain.

Thirdly, the harmful effects of eutrophication affect fish populations. For example salmonids, which spawn in deep water, suffer from eutrophication, whereas cyprinids survive better. Eutrophication weakens conditions for breeding and for juvenile fish. 
Increasing base production caused by eutrophication increases sedimentation and oxygen consumption of bottom water, makes the water muddy and increases $\mathrm{pH}$ (Tammi 1996).

Fourthly, the nutrients of the ecosystem may also be decreased due to fishing. Phosphorus and nitrogen are removed from waters along with the fish harvest. For example, fishing of Baltic herring is a net outtake of nutrients from the (eutrophied) Baltic Sea. This aspect should be taken into account in LCAs related to fishing.

\subsection{State of the art}

The state of the art and research needs for life cycle impact assessment (LCIA) were recently presented by Finnveden and Potting 1999 and Potting et al. 2002. In general, it can be said that modelling of aquatic eutrophication is still poor compared to modelling of the atmospheric environmental problems caused by conventional emissions (Potting et al. 2002).

Multiplying nutrient emissions by the corresponding characterisation factors produces eutrophication indicators. In practice, determination of the characterisation factors in commonly used assessment methods is based on the amount of phytoplankton growth which the released nitrogen and phosphorus will support through photosynthesis according to the so-called Redfield ratio (106:16:1 (C:N:P)).

This leads to site-generic characterisation factors, which means that the same amount of a nutrient emission to the water causes the same potential impact in different environmental conditions. Of course, this does not correspond to reality. The nutrient status of the recipient (i.e. which nutrient is limiting in that environment) decides which eutrophying potential additional nutrient input will have. For this reason, there have been some attempts to develop site-specific characterisation factors of eutrophying compounds (see Potting et. al. 2002). For example, Seppälä (1999) developed a method in which the fate and effects of nutrients are taken into account. The fate of airborne nitrogen compounds was calculated by using the results of a so-called EMEP-model and the fate of waterborne nutrients discharged from inland of Finland to the Baltic Sea was based on expert knowledge. Furthermore, in the determination of site-specific characterisation factors concepts of limiting nutrients and biological availability of nutrients were taken into account. The disadvantages of the method are extensive uncertainty of input data and restriction of the assessment method to Finnish emissions due to a lack of data.

\subsection{Research needs}

In summary, there is a need to develop site-specific characterisation factors for eutrophying compounds in order to obtain more realistic eutrophication indicator results. Different spatially resolved air quality-transport, water quality-transport and run-off/leaching models should be utilized (see Huijbregts and Seppälä 2001). It is important to produce results at least on the continental level. In this way, it is also possible to calculate a normalisation factor for European emissions. Normalisation factors are needed for each impact category in order to interpret the importance of different impact categories. In addition, there is a need to assess more accurate nutrient emissions from diffuse sources (e.g. from agricultural soil) to watercourses. 
Furthermore, the current fate factors for transport of airborne nitrogen emissions via soil to the aquatic environment, knowledge about differences in the biological availability of nutrients originating from different sources and regional scale data on the sensitivity of aquatic ecosystems including limiting nutrients should be improved (Huijbregts and Seppälä 2001).

\subsection{References}

Finnveden, G. \& Potting, J. 1999. Eutrophication as an Impact Category. Int.J.LCA 4 (6): $311-314$

Huijbregts, M.A. \& Seppälä, J. 2001. Life Cycle Impact Assessment of Pollutants causing Aquatic Eutrophication. Int.J.LCA 6 (6): 339-343.

Kristensen, P. \& Hansen, H.O. 1994. European rivers and lakes. Assessment of their environmental state. Copenhagen (Denmark), European Environmental Agency. EEA environmental monographs 1.

Potting, J., Klöpffer, W., Seppälä, J., Norris, G. \& Goedkoop, M. 2002. Best available practice in life cycle impact assessment of climate change, stratospheric ozone depletion, photo-oxidant formation, acidification, and eutrophication. In: Udo de Haes, H.A., Jolliet, O., Finnveden, G., Goedkoop, M., Hauschild, M., Hertwich, Hofstetter, P., Klöpffer, W., Krewitt, W., Lindeijer, E. W., Müller-Wenk, R., Olson, S.I., Pennington, D.W., Potting, J. \& Steen, B. (eds.), Towards best practice in life cycle impact assessment-report of the second SETAC-Europe working group on life cycle assessment. Society of Environmental Toxicology and Chemistry, Pensacola. (In press).

Seppälä, J. 1999. Decision analysis as a tool for life cycle assessment. In: W. Klöpffer and O. Hutzinger (Eds.). LCA Documents, 4. Eco-Informa Press, Bayreuth.

Seppälä, J., Silvenius, F., Grönroos, J., Mäkinen, T., Silvo, K. \& Storhammar, E. 2001. Rainbow trout production and the environment. Helsinki, Finnish Environment Institute. Finnish Environment 529. (In Finnish with English summary, tables and figures).

Tammi, J. 1996. The effects of eutrophication on fishes, fish stocks and fisheries - A literature review. Finnish Game and Fisheries Research Institute, Kalatutkimuksia 103. 


\section{Working environment and LCA}

Harald Ellingsen, SINTEF Fisheries and Aquaculture, 7465 Trondheim

Ph. +47 735956 50, e-mail: harald.ellingsen@fish.sintef.no

\subsection{Background}

The working environment within the fisheries sector is and has always been below what can be accepted among most other occupations. When comparing with land-based occupations, the risk level with respect to fatalities is considerably higher within both fisheries and fish farming. For the period 1989 to 2000 the average number of fatalities per 10000 man-labour year was 8,8 in fishing and 9,8 for fish farming (Sunde and Aasjord, 2000), whereas this figure is down on 1,6 for farming and forestry (Aasjord, 2002/a) which is still on the high side. To illustrate this further, it can be noted that the 1999 average accident level for the 6 most exposed land based occupations in Norway was 1,5 .

Fishing and fish farming takes place on moving vessels or platforms exposed to the elements and involves use of heavy equipment. To expect accident levels similar to these achievable on land may be unrealistic, but the situation can not remain unchanged in the future. In 1986, the safety committee for the fishing fleet claimed that a risk level of 4,5 fatalities per 10000 man-labour years should be attainable granted that certain prescriptions were followed (NOU, 1986).

The high accident levels may be seen as an indicator of a poor working environment in general. The statistical basis for the number of injuries or near incidents within the fisheries sector not leading to disability, is more or less absent. The ratio between the various accident types is however found to be of the same magnitude (Sunde and Aasjord, 2000) as those found in other industries (Bird and Germain, 1992).

Both to the industries involved and to the community, unacceptable working conditions imply costs with respect to reduced efficiency, lost working capacity and medical treatment as the most obvious effects. Another effect is poor reputation as a future occupation for qualified youth. The Norwegian fishing industry is highly dependant on qualified personnel and can not afford missing the most competent due to a bad reputation.

The work environment imposes a considerable load on the health of those exposed to it. The Swedish research institution IVF (Anon, 2002) refer to an EU investigation of the work environment indicating that in Europe 8.000 people die in accidents at work each year. Every year, 10 million people (out of a total work population of 160 million within the EU) are injured at work or as a result of conditions related to the working environment. The cost of these accidents and injuries was estimated to the amount of SEK 25 billion.

Life cycle analyses in general focus on the effects on the external environment. The purpose of such analyses should however be to reveal the total environmental load also 
involving the personnel inside the factory walls or on board the fishing vessel. Only then, the process or product in question can be optimized in the long term perspective without sub-optimization.

\subsection{Can a better working environment be expected?}

Trends within both fisheries and aquaculture point towards an everyday life increasingly exposed to competition. Within Norwegian fish farming, the production rate has increased from 50 tons per man-labour year in 1990 to 300 tons in 2000 and is still rising (Anon. 2000). The trend goes in direction of larger units and concentration of plants, use of more mechanized and heavy equipment and fewer workers. It is uncertain how this will influence the working environment.

Within capture fisheries a similar development takes place. Generally the fisheries are steadily more exposed to competition leading to efficiency improvement measures. One driving force in this context is over-capacity which is a world wide problem. Globally the over capacity is roughly calculated to be between $30 \%$ and $50 \%$ (Garcia and Moreno, 2001). Although the Norwegian fishing fleet has undergone a comprehensive process of restructuring throughout the 1990s, figures from the Norwegian Directorate of Fisheries (Hallenstvedt \& Søvik, 1996) show that there is a significant over-capacity, for example in the cod-fishing fleet. While the number of registered Norwegian fishing vessels was reduced from around 27000 in 1980 to around 13000 in 1999, the total tonnage has remained almost unchanged around $300000 \mathrm{BRT}$.

Norwegian fishing vessel designs are restricted by a complex regulation system. The motivation behind these restrictions is the need to limit or reduce the total catching capacity of the fleet. Length restrictions are frequently used as certain fisheries are closed for vessels above certain length steps. The design and building of the vessels must take these regulations into consideration which has resulted in the so-called "paragraph" vessel designs.

The productivity within certain vessel groups has however, over the years, increased dramatically and within some length groups (especially 25 to $27,5 \mathrm{~m}$.) with as much as $200 \%$ (Standal, 2001). In spite of the length restrictions, there has been a strong increase in breadth, depth and gross tonnage. Increased light ship weight is a result of the increased complexity, performance and size. Increased engine power, larger winches and so on is needed for powering of heavier and less efficient hulls and heavier fishing gear. It can be concluded that changes in technical parameters like increased engine and winch power, gross tonnage and cargo space represent a strong increase in catching capacity, in spite of the aim of the regulation policy.

Broad and short hull forms with increased depth and height have also proved to be working places of inferior quality with unpleasant motions, crowded workspaces and high risk levels both with respect to crew injuries and vessel casualties (Degnbol (ed.), 2002). Also Norges Fiskarlag (Anon., 1998) has pointed out the effects of this regulation policy as strongly negative both for economic, operational and safety reasons. Aasjord (2002/b) has documented several unfortunate examples where attempts to squeeze vessel designs in under the regulations have resulted in vessels with both sub standard working conditions and low level of safety. 
The safety level varies however within the fishing fleet. Below table (Aasjord, 2002/c) is based on statistics collected by SINTEF Fisheries and aquaculture and official data and shows that the risk level is considerably higher on small fishing vessels. Typically the risk for capsizing is greater for smaller vessels as well as the risk for falling overboard for various reasons.

\begin{tabular}{|c|c|c|c|c|}
\hline Period of Jan. 1989 - June 2002 & $\begin{array}{c}\text { Small fishing } \\
\text { boats }\end{array}$ & $\begin{array}{c}\text { Medium size } \\
\text { vessels }\end{array}$ & $\begin{array}{c}\text { Deep sea } \\
\text { fishing vessels }\end{array}$ & $\begin{array}{c}\text { Total fishing } \\
\text { fleet }\end{array}$ \\
\hline Fatal accidents & 125 & 61 & 53 & 239 \\
\hline Calculated man years (1995) & 5650 & 6390 & 9590 & 21630 \\
\hline Risk of fatal accidents & 17,7 & 7,6 & 4,4 & 8,8 \\
\hline
\end{tabular}

Standal (2001) has shown a trend towards a significant decrease in the number of small vessels. Although the number of vessels slightly decrease inside the larger vessels groups as well, the great capacity increase is registered here. This may imply a possible working environment improvement caused by an ongoing restructuring process from smaller to larger vessels.

\subsection{LCA and the working environment}

The aim of using LCA in this context must be to improve the working environment on the fishing vessels and on the fish farming plants in an overall and long term view. The working environment aspect must be integrated in the design processes and tools for life cycle design work. This is not the case within the fisheries sector at present. A stronger emphasis on the working environment in the life cycle perspective may contribute to stronger consciousness among designers, shipping companies, fish farming companies and governmental bodies.

To achieve this, both better design procedures and design tools are needed. Such procedures and tools are already developed for other, land based sectors (Nyström, 2000), but are lacking for the fisheries.

SINTEF Fisheries and aquaculture is however in the process of developing a LCA-tool for design of fishing vessels where the working environment effects will be integrated (Ellingsen et. al., 2002). This work will be strengthened in the years to come. 


\subsection{References}

Anon. (1998) "Kostnadsdrivende regelverk for norsk fiskeflåte", rapport fremlagt av styringsgruppe nedsatt av Norges Fiskarlag

Anon. (2000) "Nøkkeltall fra norsk havbruksnæring", The Direktorate of the Fisheries, internet address: www.fiskeridir.no

Anon. (2002) "Why include the work environment in Life Cycle", IVF Industrial Research and Development Corporation, reference to internet address; http://www.ivf.se

Bird F. and Germain G. (1992) "Practical Loss Control Leadership”, International Loss Control Institute

Degnbol P. (editor), Carlberg A., Ellingsen H., Tonder M., Varjopuro R. and Wilson D. (2002) "Integrating fisheries and environmental policies: the Nordic experiences and the CFP", a report prepared for The Nordic Council of Ministers, The Fisheries-Environment strategy programme

Ellingsen H., Fet A. and Aanondsen Aa. (2002) "Tool for Environmental

Efficient Ship Design”, ENSUS 2002, University of Newcastle upon Tyne, UK, December 2002

Garcia S. M. and Moreno I. L. (2001) "Global overview of marine fisheries, Reykjavik conference on responsible fisheries in the marine ecosystem", Reykjavik, Iceland 1- 4 October 2001

Hallenstvedt, A. og Søvik, G. (1996) Struktur- og kapasitetestilpasning i kystflåten. Norges Fiskerihøgskole/Universitetetet i Tromsø.

NOU 1986:10 (1986) “Sikkerhet i fiskeflåten”, Universitetsforlaget A.S

Nyström B. (2000) "Databas för livscykelanalys - arbetsmiljö (Behov ock arbetsskadestatistik i olika länder)”, IVL Svenska Miljöinstitutet AB, B 1397, Stockholm 2000

Standal, D. (2001) Moderniseringsprosesser i kystflåten - Om teknologisk endring og institusjonutforming, Økonomisk Fiskeriforskning, 0803-6799/11:2001/1+15

Sunde A. and Aasjord H. L. (2000) "Safety measures aimed at reducing accidents among Norwegian fishermen", World FishTech 2000, Trondheim, Aug. 2000

Aasjord H. (2002/a) ”Døde etter næring i årene 1998 - 1999 - 2000 - utvalgte næringer”, Internal report, SINTEF Fisheries and Aquculture 2002

Aasjord H. (2002/b) "Paragrafbåter i norsk fiskeri - om konsesjoner, flåtefornying og kapasitet", SINTEF Fisheries and Aquculture 2002

Aasjord H. (2002/c) "Status for accidents, safety and working conditions in the Norwegian fishing fleet", Internal report, SINTEF Fisheries and Aquculture 2002 


\title{
7 Anti-fouling agents in seafood production
}

\author{
Mikkel Thrane \\ Aalborg University, Department of Development and Planning \\ 9220 Aalborg Oest, Denmark \\ E-mail: Thrane@i4.auc.dk
}

\subsection{Background}

The chemicals, which have achieved most attention in the fishery is by far anti-fouling agents used to prevent algae and other marine organisms to settle and grow on the hull of the ships, also termed marine bio-fouling. Anti-fouling agents prevent marine biofouling, which otherwise would result in higher fuel consumption and lacking maneuvering capabilities. The biocides, which have been used so far, mainly consist of copper and/or tin compounds such as TBT, Zinc-pyrithione, Diuron and Irgarol (Lassen et al., 2001).

Anti fouling agents are supposed to kill and demobilize living organisms. However, the problem is that previous types of anti fouling agents have affected not only the target organisms, but a wide array of marine life. Furthermore, they have been characterized by a relatively low biodegradability and the ability to accumulate in the food chain. Consequently, the effects are now widespread in the ecosystem. Mollusks are particular sensitive to biocides such as TBT and for certain types of snails sex changes have appeared in all areas of the Danish waters ${ }^{1}$ (Foverskov et al., 1999; Strand and Jacobsen, 2000).

The fishery is only "one" among many factors contributing to the pollution with antifouling substances. Shipping as such, is probably the overall most important factor. Still, LCA-studies in Denmark have shown that the emissions of anti-fouling agents based on copper and or TBT, represents one of the most important impact potentials for all types of fish products (Thrane, 2004a). The uncertainty of toxic impacts in present LCA models are substantial, but considering the magnitude of the impact potential as

\footnotetext{
1 TBT is able to bio-accumulate in the food chain. Some of the highest concentrations are found in Sea Porpoises. In laboratory tests it has been rendered probable that TBT and its decomposition products can weaken the immune system among animals and increase the risk of cancer among humans. In foreign studies there is found alarming concentrations of butyltin (the decomposition product from TBT) in the blood from humans that may originate from consumption of fish and shellfish (Foverskov et al., 1999; Strand and Jacobsen, 2000).
} 
well as the effects that have been observed in the marine ecosystem, it is certainly a problem worth addressing ${ }^{2}$.

The emissions of anti fouling agents from different vessel segments in Denmark have been analyzed in Thrane (2004a). The analysis shows that mussels, pelagic fish and industrial fish represents the smallest emissions per $\mathrm{kg}$ caught fish/shellfish. Regarding farmed fish, it's estimated that $3-5 \mathrm{~kg}$ of industrial fish is used to produce one $\mathrm{kg}$ of farmed fish. This means that the consumption is still relatively low per kg farmed fish as well ${ }^{3}$ (Ministry of Food, Agriculture and Fisheries, 2001)

The largest emissions per kg caught fish appear for codfish, flatfish, prawn/shrimp and Norway lobster. In other words it is demersal fish and shellfish, which represents the largest emissions. This is the same picture as for energy consumption and seafloor impacts - which have been analysed in Thrane (2004a) and Thrane (2004b) as well. In absolute terms the emissions from demersal fish and shellfish constitute more than $2 / 3$ of the total emissions from the Danish fishing fleet.

It is also established that small vessels, in average, represents larger emissions of anti fouling agents per catch volume compared to larger vessels. This tendency is opposite to the tendency for energy consumption (Thrane, 2004a).

\subsection{Development tendencies}

Concerning antifouling agents, it is reasonable to believe that we will face a radical technological change in the years to come.

The International Marine Organisation (IMO) has recommended that TBT was phased out in 2003 and that TBT-based products on hulls are completely removed in 2008 - for all ships. Not all countries have ratified the IMO convention, but in EU the member states have already decided to implement the ban of TBT. In Denmark, the latest regulation of antifouling agents from 2003 also restricts the use of copper compounds by limiting the leaching per surface area.(Allermann, 2004).

It is still allowed to use copper compounds and certain biocides. The major producers of antifouling agents have already developed series of tin or TBT free paints, but with a relatively high content of copper. Even though large amounts of copper is used, it is reasonable to believe that the toxicity levels emitted from fishing vessels will decrease considerably in the following decades.

\footnotetext{
${ }^{2}$ Organotin compounds, mainly from ships, are spread in all parts of the marine ecosystem and are found in considerable concentrations in whales and birds on the open oceans. The concentrations are largest in coastal regions and sailing routes and sediments is a potential sources because the substances may be released again, especially sediment from harbors and sailing routes are removed ( Strand and Jacobsen, 2000)

3 Apart from the indirect consumption of anti fouling agents through industrial fisheries, they are used in sea based aquaculture, where it prevents marine bio-fouling on the cages. This is not taken into consideration here.
} 
Exactly how much the pollution levels will be reduced and how fast the new products will diffuse, is difficult to predict.

\subsection{Research needs}

As mentioned LCA models often have a substantial uncertainty, especially when it comes to toxicity. When assessing the environmental impact from fish products in the future, it is important to incorporate information from Chemical Risk Assessment studies - especially when it comes to new anti fouling agents that do not appear in existing databases. In Thrane (2004a) this has been done qualitatively, but it would be relevant to further develop LCA methods to incorporate such data on a quantitative basis. In addition, it is necessary to further develop LCA methods to reduce the uncertainty for toxicity in general.

Another interesting research perspective would be to further analyze the human health impact potential related to anti fouling agents. Obviously, this would require that the assessment included the exposure through consumption of fish products, but it could also include the impacts during the production of chemicals and not least the painting process. 


\subsection{References}

Allermann, K., I. Schneider, E. Walstrøm, B. H. Andersen, T.T. Andersen, H. Højevang, 2004.

Substitution af biocider I bundmaling til skibe med enzymer [Substitution of biocides in antifouling paint to whips with enzynes]. Miljøprojekt 910. Copenhagen: Miljøstyrelsen.

Foverskov, S. et al., 1999: Bundmaling til skibe - et miljøproblem [Antifouling paint to ships - An environmental problem ?]. Tema rapport fra DMU, 30/1999, Miljø- og Energiministeriet, København

Lassen, C., S. Vaaben, and E. Hansen, 1997. Massestrømsanalyse for tin med sarligt fokus på organotinforbindelser [Substance Flow Analysis for tin with focus on organotin]. Arbejdsrapport fra Miljøstyrelsen, nr. 7, København.

Ministry of Food, Agriculture and Fisheries, 2001. Facts on the Industrial Fisheries. Ministry of Food, Agriculture and Fisheries, Denmark

Strand, J., and A. J. Jacobsen, 2000. Forekomst af organiske tinforbindelser i planter og dyr fra danske farvande: Akkumulering og fødekcederelationer [Organotin in plants and animals from danish waters Accumulation and foodchain aspects]. Arbejdsrapport fra DMU, nr. 135, Afdeling for havmiljø.

Thrane, M., 2004a. Environmental Impacts from Danish Fish Products. PHD dissertation, Department of Development and Planning, Aalborg University, Denmark.

Thrane, M., 2004b. Energy consumption in the Danish fishery: Identification of Key Factors. Journal of Industrial Ecology Vol. 8 Number 1 p. 223-239

Ziegler, Frederike et al., 2003. Life Cycle Assessment of Frozen Cod Fillets Including Fishery-Specific Environmental Impacts, International Journal of Life Cycle Assessment 8 (1) 39- 47 (2003). 


\title{
8 Fish welfare
}

\author{
Berit Mattsson $^{1}$, Mikkel Thrane ${ }^{2}$ \\ ${ }^{1}$ SIK, the Swedish Institute for Food and Biotechnology, P.O.Box 5401, SE-402 29 \\ Göteborg, Sweden, Ph. +46 31335 5600, e-mail: bm@sik.se \\ ${ }^{2}$ Aalborg University, Department of Development and Planning, 9220 Aalborg Oest, \\ Denmark, e-mail: Thrane@i4.auc.dk
}

\subsection{Background}

Animal welfare issues have been much under debate over the last few years, however fish have not really been in focus yet. One likely reason is that people in general do not have the same empathy for fish as for mammals. The question is if this perception is relevant?

Fish, like other vertebrates, have highly sensitive sensory organs which react to stress through transport, encaging, pollution and other similar factors (Reichenbach-Klinke, 1987).

"The pain system in fish is virtually the same as in birds and mammals", Dr. Donald Broom, professor of animal welfare at Cambridge University is quoted on the website fishinghurts.com. A great number of websites are available on the fish welfare issue. Some of them focus on sports fishing, others on professional fishery but probably most of them on aquaculture.

\subsection{State of the art}

Animal Protection Laws require, among other things, that animals be kept under conditions where they can express behaviour and are not harmed by the culture methods (Peters, 1990). For aquaculture there are rules and regulations concerning the fish density and for slaughter. It seems that farming fish means taking on a greater responsibility for fish welfare. It makes sense considering the fact that there is a human impact throughout the whole lifetime of the fish in aquaculture, while the suffering is more limited in time when you speak about wild caught fish.

There are animal welfare policies available for aquaculture. One example is shown below (www.selonda.com):

- Provision of a stress free environment for the fish.

- Ensuring all husbandry tasks are carried out to minimise a detrimental impact on the fish stocks.

- Providing immediate treatment to diseased or stressed fish.

$\circ$ Organising the production operation to take into account the health and welfare of the fish stocks and prevent disease.

$\circ$ Ensuring that the farmed fish are humanely slaughtered under hygienic conditions 
Professor Rose concludes in a recent study (Rose, 2002) that behavioral responses to noxious stimuli are separate from the psychological experience of pain and that awareness of pain in humans depends on functions of specific regions of the brain called "cerebral cortex". He remarks that fishes lack these essential brain regions or any functional equivalent, making it unlikely that they can experience pain:

"Because the experience of fear, similar to pain, depends on cerebral cortical structures that are absent from fish brains, it is concluded that awareness of fear is impossible for fishes. Although it is implausible that fish can experience pain or emotions, they display robust, nonconscious, neuroendocrine, and physiological stress responses to noxious stimuli" (Rose, 2002)

When other researchers have concluded the opposite, it is because they have mistaken pain and the ability to register noxious stimuli, he states. It is like for humans that are anaesthetized under an operation. The person may react on physical external noxious stimuli, but the patient cannot feel the pain. Acknowledging that research in neurological behavior and consciousness is a new and very difficult field of research, it is difficult to conclude anything decisive on the matter.

\subsection{Research needs}

Animal welfare issues are sometimes listed as one of the impact categories relevant for LCAs on animal production, however it is not normally included. For farm animals it is clear that many consumers consider animal welfare issues more important than environmental issues. No similar investigation has been found for fish.

It is likely that there is a conflict between environmental issues and the fish welfare issue for wild caught fish, i.e. that from and animal welfare point of view fish caught in nets should not stay in the nets too long which means a higher fuel consumption and a larger amount of emissions per kg of product. However, the product quality should be improved.

Studies of the suffering of fish caught in different types of fishing gear have not been found in this survey.

\subsection{References}

Peters, G. Animal welfare problems in the mass raising of commercial fish. Dtsch Tierartl Wochenschr 97(4):157-60.

Reichenbach-Klinke, H.H. 1987. Fish and natural protection. Tierartl Prax 15(1):99-106.

Rose, J.D. (2002). The neurobehavioral nature of fishes and the question of awareness and pain. Reviews in Fisheries Science 10(1), 1-38. 


\section{Workshops}

In this chapter summaries will be presented of the five workshops performed during 2001-2002 within the network project.

- Workshop 3 The ISO database format

Fishing vessels, anti-fouling

- Workshop 4 Fish industry, distribution, packaging \& consumer phase

- Workshop 5 Dissemination of results from the network project

\subsection{Workshop 1: Göteborg, February 26-27, 2001}

Startup, national projects, database formats and Swedish fishery administration (organised by Berit Mattson and Friederike Ziegler)

Participants:

Jens Munk

DTI

Denmark

Tommas Leth

DTI

Denmark

Mikkel Thrane

Aalborg University

Denmark

Halla Jónsdóttir

IceTec

Iceland

Kristin Hassel

SINTEF

Norway

Helga R. Eyjólfsdóttir

IFL

Iceland

Friederike Ziegler

SIK

Sweden

Berit Mattsson

SIK

Sweden

Thomas Ohlsson

SIK

Sweden

Invited speakers:

Raul Carlson

CPM

Sweden

Lisa Person

CIT

Sweden

Pär Olsson

SIK

Sweden

Staffan Larsson

National Board of Fisheries

Sweden

Anita Tullrot

National Board of Fisheries

Sweden

Bengt Kåmark

National Board of Fisheries

Sweden 


\section{On-going national LCA projects}

Norway: At SINTEF, a project is on-going that concerns LCA from the designer's point of view. It is called "The fishing vessel -a part of the production chain" and studies the fishing vessel with a life-cycle perspective. Since fuel is the largest economic running cost during the life-time of a fishing vessel, the fishing company or fisherman owning it becomes more independent of world market fuel prizes if energy-efficiency is considered already in the construction phase of a vessel. The constructor can identify "problem areas" and try out alternative solutions that will save both economy and environment at an early stage.

Denmark: At Aalborg University, a Ph.D. project is going on which concerns LCA for Danish consumption fish. Screening methods are developed for four different seafood products as a basis for environmental product development and eco-labelling. The Danish Technological Institute (DTI) is participating in a national project on "Life cycle aspects of basic food". A part of this project concerns marine products, in particular, a case study is planned about farmed fish and its feed based on fish meal.

Iceland: IFL and IceTec are currently working on a national project concerning life cycle assessment of cod produced and manufactured at Icelandic processing trawlers.

Sweden: At SIK a project is running called "Environmental assessment of seafood products with a life-cycle perspective" aimed at methodological development to include marine environmental impact such as seafloor impact and by-catches in LCA. A case study on a cod product fished in the Baltic Sea has been finished as well as a study on the fuel combustion and emissions in the Swedish cod-fishing fleet.

\section{Database format}

Some invited guest lecturers presented database formats from different points of view; they were Raul Carlson from CPM, Lisa Person from CIT and Pär Olsson from SIK. Raul presented a Swedish (internationally) documented and fully reviewed LCA database built on SPINE, Lisa presented LCAiT4 which is up to a point based on SPINE and Pär presented a Swedish project " IRIS-LCA database" where industrial research institutes put data in a database catalogue. This structure of this catalogue is also based on the SPINE database format. After that the participants discussed how they could use this information to build our own database and how we should proceed with this.

In Denmark there is a another database format developed by the industry which is called SPOLD. The question is if it is maybe more useful for us. Is it better to have small amount of data well documented or a lot of data not so much documented? The participants agreed on minimum standard and that is:

- Reference for the data

- Geographical data

- Information about the origin

We decided that it is too early to decide a definite format for our seafood data and that we will wait for the ISO standard 14048 which is underway. 


\section{Fishery administration}

A visit at the Swedish National Board of Fisheries was organised by Staffan Larsson. Several presentations were made regarding the Swedish fishery administration, the national environmental goals with relation to fishery as well as the current status of the development of an eco-labelling scheme for seafood.

\section{Methodological questions}

It was also on the agenda, to discuss problems concerning functional unit, allocation and system boundaries. The participants had been asked to bring their specific problems to the workshop and discuss them there. Several problems were discussed:

\section{Allocation:}

In the Swedish project there are questions if it is better to use economical allocation vs. mass allocation because the fisherman catches both Norway lobster and cod at the same time. It was pointed out that if it was possible, it would be useful to expand the system boundaries (find system catching only the other species) and use that as a part of the system. If that is not possible the economical allocation would be better.

When the Icelandic trawlers sail far away to fish, the purpose is to catch cod. Although they also get several other species, both that can be used commercially and other that is not commercial. Also when manufacturing the fish there are several by-products not as valuable as the main product. Everybody agreed on that economical allocation is better than mass allocation.

\section{System boundaries:}

After the shipping of the fish from Iceland to European countries there is a huge and complex transport net for selling the fish. In some cases it is used as a raw material for further processing and sometimes it is sold on the open market. The question is if the analyses should contain everything or if it would be possible to let the system boundaries end at the harbour. It was considered better to follow one stream (the most common one) and look at the others as by-lines.

\section{Functional unit:}

The question was raised if it was necessary to use some criteria for the quality as an index for the functional unit in order to be able to compare different studies. No conclusion was reached but the participants agreed on that this was certainly something to have in mind when choosing the functional unit.

\subsection{Workshop 2: Hirtshals, August 15-17, 2001.}

Including fishery-related marine environmental impact in seafood LCAs (organised by Mikkel Thrane and Friederike Ziegler)

From August 15 to 17, 2001, 18 participants and invited lecturers gathered at the North Sea Centre in Hirtshals, Denmark, to discuss the marine environmental impacts caused by fishery and how to relate to them when performing LCA studies for seafood products. This was the second workshop of the "Nordic network for LCA of seafood". Presentations were divided into three main topics; the first day was focused on seafloor effects of trawling fishing gear and also included a lecture about an ecological network 
of Danish fishermen. During the second day, the direct and indirect ecosystem effects of fishery, with the Baltic Sea as an example, and the use of toxic anti-fouling paints on the hulls of fishing vessels were discussed. The third day was dedicated to discussions of ways of getting closer to a methodology for handling the discussed environmental effects in a seafood-LCA. Two working groups discussed separately and then presented results. It was a general opinion that discarding, use of anti-fouling, ecosystem effects and seafloor impact should be assessed qualitatively and, if possible, quantitatively in a seafood-LCA. For some of them, concrete units were discussed, while for others it was decided that they are important but cannot be quantified in a reliable way at this moment. Participants with different backgrounds contributed to fruitful discussions and the workshop has led to an increased level of knowledge about these issues in the network, as well as created new contacts. To continue this work, it was decided that the members of the network should be responsible for gathering information about one of the topics each and discuss case studies during future workshops.

Participants:

Mikkel Thrane

Erling Larsen

Berit Mattsson

Friederike Ziegler

Frans Silvenius

Helga R. Eyjólfsdóttir

Halla Jónsdóttir

Kristin Hassel

Staffan Larsson

Ole Norden Andersen

Bo Storrank

Mette Bertelsen

$\underline{\text { Invited speakers: }}$

Per Dolmer

Ulrik Jes Hansen

Per Nilsson

Knud Andersen

Olle Hjerne

Yvonne Walther

$\begin{array}{ll}\text { Aalborg University } & \text { Denmark } \\ \text { DFU } & \text { Denmark } \\ \text { SIK } & \text { Sweden } \\ \text { SIK } & \text { Sweden } \\ \text { FGFRI } & \text { Finland } \\ \text { Icelandic Fisheries Laboratories } & \text { Iceland } \\ \text { IceTec } & \text { Iceland } \\ \text { SINTEF } & \text { Norway } \\ \text { National Board of Fisheries } & \text { Sweden } \\ \text { Skov og Naturstyrelsen } & \text { Denmark } \\ \text { Miljöministeriet } & \text { Finland } \\ \text { ICES } & \text { Denmark }\end{array}$

DFU Denmark

SINTEF Denmark

Göteborg University Sweden

The fishermens ecological network Denmark

Stockholm University Sweden

Baltic Sea Research Station Sweden 


\section{Summary of presentations}

\section{Per Dolmer: Fishery impact on benthic ecosystems}

The first part of Per Dolmers presentation concerned the general knowledge about seafloor effects of towed fishing gear. He showed that fishing intensity is rarely evenly distributed, but rather concentrated to certain areas and pointed out that the type of habitat impacted and the type of fishing gear used is important when discussing recoverability or recovery time. There are indirect benthic effects of fishing activities in addition to direct effects, scavenging species are e.g. favoured by the increased availability of food after passing of a trawl or dredge, killing or damaging some benthic animals. His management recommendation was to reduce effort, reduce effort and reduce effort. One way to do that is to protect certain areas from fishing, i.e. create marine protected areas designed to protect important spawning areas and a discussion on the possible effects of such actions followed.

The second part of the presentation concerned a case study of benthic effects of mussel dredging in Limfjorden in Denmark which Per Dolmer has been involved in.

The mussel stock in the Limfjord has increased which has caused the growth of this fishery into what it is today. The mussels are harvested by dredges physical impact includes increased re-suspension and sedimentation and altered habitat structure. Biological impact includes changes in planktonic communities and benthic flora and fauna; some species decrease, others increase. Chemical impact, by means of altered nutrient cycles, is also caused by the mussel dredging. The outtake of mussels e.g. leads to a decrease in nutrients in an enclosed and sometimes eutrophied fjord. The mixing of water masses caused by the fishing can help decreasing the risk of oxygen-depletion and even algal blooms, since a stratified water column is required for a bloom to develop.

\section{Ulrik Jes Hansen: Fishing gear}

Ulrik Jes Hansen gave a presentation about the function and energy efficiency of common gear types: fish traps, driftnets, gillnets, pots \& creels, longlines, purse seines, Danish seines and trawls. He summarised his view on the sustainability criteria of different fishing gear in the following table: 


\begin{tabular}{|l|l|l|l|l|l|l|}
\hline & $\begin{array}{l}\text { Species and } \\
\text { size diversity }\end{array}$ & Selectivity & $\begin{array}{l}\text { Fuel } \\
\text { consumption }\end{array}$ & $\begin{array}{l}\text { Environmental } \\
\text { impact }\end{array}$ & $\begin{array}{l}\text { Economic } \\
\text { viability }\end{array}$ & Quality \\
\hline Trawl & Very good & Poor & Very poor & Poor & Good & Poor \\
\hline Danish seine & Poor & Good & Poor & Good & $?$ & Good \\
\hline Gillnet & Poor & Good & Good & Good & $?$ & Poor \\
\hline Purse seine & Very poor & Very poor & Good & Very good & Good & Very good \\
\hline Longline & Poor & Good & Good & Very good & Good & Very good \\
\hline
\end{tabular}

Catch quality of different fishing gear was discussed as were different types of fisheries and their sustainability

\section{Per Nilsson: Seafloor effects of fishery}

Seabed changes are potentially important, e.g. changes in nutrient cycling in near-shore sediments can be very important locally. The effects have to be evaluated in each area and by each type of gear, though, it is difficult to generalise these types of effects. Per Nilsson talked about the practical difficulties in designing experiments on trawling effects without confounding effects with natural differences between marine ecosystems in different areas due to a lack of unfished areas with similar conditions as fished sites, demonstrating some kind of "reference state". As an example, work that was done in the Gullmar fjord in Sweden was presented, where the rare situation had occurred that the fjord had been closed to fishery for some years and the authorities wanted to assess whether opening the fjord for a limited fishery would harm the ecosystems or not. After the study was completed, restricted trawling was allowed in the fjord.

He then continued by showing video recordings from the Swedish west coast demonstrating trawl marks of $10-70 \mathrm{~cm}$ depth in the seafloor. They are still physically still visible after 9 years, but the tracks are recolonised by benthic animals.

Comparative experiments (before/after or fished/unfished) are very expensive, however another approach to investigate the fishery impact on seafloors was presented, using Geographical Information System (GIS) software and effort data from logg-books to show distribution and intensity of seafloor disturbance. Combining such an "effort map" with maps of sediment characteristics (telling something about the type of benthic community living there) can give a rough idea of the seafloor impact of that fishery. A problem is the lack of exact geographic data on fishing effort (as well as lacking data on 
benthic habitat distribution), but the development of technical management tools such as the vessel monitoring system (VMS) could facilitate such work in the future.

\section{Knud Andersen: The fishermens ecological network}

Organisation with 28 fishermen members who have developed an environmental certification scheme for different fisheries. The goals of the organisation, incorporating the point of view, knowledge and skills of the fishermen in the work process include:

- Take care of the marine environment by minimising the effects from the use of different fishing gears

- Minimise the catch of fry and other by-catch

- Reducing energy consumption compared to catch volume and catch value

- Save the sea non-organic waste by minimising the loss of fishing gear and not to throw this waste over board

- Create attention to the pollution of the sea- if necessary to stop fishing in polluted areas.

- Develop nature-friendly fishery-creating the background for sustainable coastal societies

- Promoting a fishery that increases practising fishermens' share of the value of the fish

- Produce best quality possible by careful treatment of the catch.

\section{Yvonne Walther: The International Baltic Sea Sampling Programme (IBSSP)}

Yvonne Walther is participating in the EU -funded IBSSP, a program with the purpose build a database and provide detailed information related to catch, by-catch and discard from different fisheries in the Baltic Sea with the long-term goal of improving stock assessment for Baltic cod. In the Kattegat, trawl and gillnet fisheries targeting cod; trawl fisheries for Norway lobster, herring as well as industrial and mixed fisheries (in the latter four cases, cod is taken as by-catch and/or as discard) are sampled. In the Baltic Sea trawling targeting cod, herring and industrial fisheries is sampled as well as cod gillnets. Data gathered covers everything from gear, target species, position, fishing time, depth, length and weight of species, discard weight, number of nets, size of trawl, age and length, weight and maturity.

Yvonne then spent some time on defining the word discards as fish that is thrown overboard because it is of non-marketable size or species, a prohibited species, damaged or when high-grading occurs (discard of fully marketable fish due to quota limitations). A clear distinction should be made between by-catch and discard. By-catch is landed and discard thrown over-board. Some results so far:

- Discard is often almost $1 / 2$ of the total landings

- Discard as a function of age shows that it is typically one and two year old fish and a little part of three-year-old fish.

- Fish up to five years old are also discarded if they are damaged.

- In the western part of the Baltic Sea the discard of trawl fishery is much larger compared to gill net, but the opposite seems to be the case in the eastern part. One reason could be that there are fewer fish in the eastern part. Therefore, the nets are left out for a long time. But there are also other possible reasons. However, the results show that there is a larger part of older discarded fish in gill net fishery. 
Olle Hjerne: Ecological effects through food-web interactions caused by fishery

Olle Hjerne focused on the effects in the food-web from fishery. He started by stating that fishery actually increases the mortality of pelagic fish by $100 \%$ and by $500 \%$ for predatory fish. We accept this huge and continuous environmental impact, because the fishery provides us with a lot of benefits and because we are not aware of the ecological effects under the sea surface.

In the Baltic Sea there are two important factors limiting the spawning of cod; the oxygen level and the salinity of the water. The volume of water where the values of these two variables are sufficient to allow cod spawning is naturally small and has decreased even more due to eutrophication, among other things. Important sources of eutrophying emissions are agriculture and combustion of fossil fuels.

Some examples of ecosystem effects of changing fishing pressure in the Baltic (cod, herring and sprat constitute around $80 \%$ of the fish biomass) were presented. When the biomass of sprat is high, the biomass of cod is low and opposite. Research results seem to confirm the thesis of "alternative ecosystem states", which means that there are different stable states that an ecosystem can reach and to go from one to the other requires that something extraordinary happens. According to this thesis, one solution to the cod problem could be to fish down sprat to help the cod to recover (speculations). Ecosystem changes can be direct, but also indirect, several steps away from the fished species on competing species or prey species and, in turn, their prey. Such effects transplanting themselves up or down a food web are called cascading effects. 
Fig. 3 Foodweb from the Baltic Sea. Including fishery mortality of cod would make it even more complex.

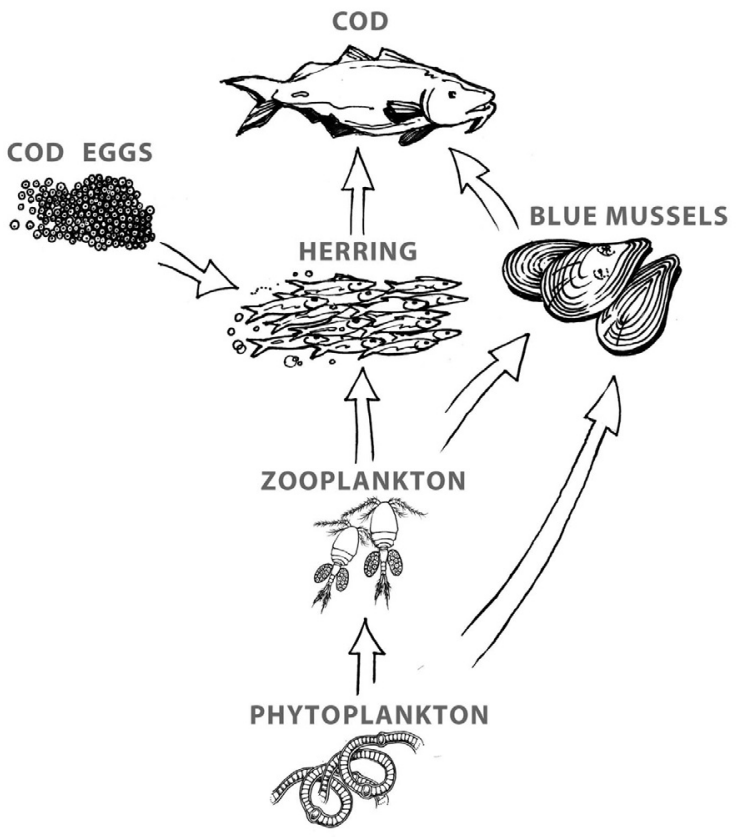

A suggested indicator for the impact on the target species could be:

(Predation+Fishery)/Production

If this index is over 1 that means the stock is decreasing, if it is less than 1 it means the stock is increasing.

The difficult question is: What is an acceptable impact on the ecosystem? You can increase the fishery to maximise the profit. If you maximise even more you can chose to stop when you have the largest catch volume. But if you increase fishery even beyond that point, the catches will be reduced and that is where we are today.

Another important question is: What is a healthy ecosystem? This is difficult to describe and will always be based on some subjective assessment

Some possible indicators for a healthy ecosystem:

Biodiversity: Number of species and evenness between them

Community structure: The relation between predatory fish and prey fish

Age structure: Actually older cod females are better spawners because they lay more eggs and the eggs are bigger and float better.

Indicator species: For example it is possible to use birds as an indicator. If the birds live of the population of interest, and bird populations do not decrease - the fish population is probably $\mathrm{OK}$ as well. 


\section{Per Nilsson: Marine bio-fouling and new methods to fight it}

Marine bio-fouling (biological organisms attaching to the surface of the ship) is an old problem that needs new solutions. The problem with marine bio-fouling is that:

- It degrades surfaces e.g. ship worms and corrosion

- It increases hydrodynamic friction

- It increases the weight - this a big problem in aquaculture farms and off-shore installations

- It reduces the heat exchange in cooling systems using seawater.

There are also benefits from marine bio-fouling:

- It helps the settling of larvae in aquaculture

- It can help the degradation of biological matter in sewage systems.

Economic costs of marine bio-fouling are high. The annual cost of bio-fouling for the global shipping industry is aproximately 3,5 billion US dollar and $5 \%$ bio-fouling on a super tanker increases the fuel cost with around 1 million US dollar per year. The most used anti-fouling paints are based on: Organotin (TBT) - the most effective, Copper oxide, Irgarol and/or Diuron. The problems are that these substances are broadly toxic with effects on many types of marine life, including fish and birds. It causes an increasing load of heavy metals ( $\mathrm{Sn}, \mathrm{Cu}$ ).

TBT is phased out globally from 2003. Copper use is limited in coastal areas (Sweden, Denmark and the Netherlands). In the Baltic Sea no toxic paint is actually allowed on smaller vessels from 2001 (fouling is a much smaller problem there due to the brackish water).

New solutions under development for future, less harmful, bio-fouling protection are:

- Surfaces with low adhesion (e.g. silicones). This also decreases the fuel consumption, but it does not seem to last very long.

- Physical repellent surfaces - something that can be used for e.g. aquaculture, where the surface of pipes etc. has a structure which prevents bio-fouling.

- Substances with specific effects on fouling organisms instead of being harmful to many species.

- Rapidly degrading substances with low degree of bio-accumulation

- Mechanical cleaning

- Fresh water treatment

A Swedish project was then presented where the focus has been on barnacle fouling. So far research showed that the barnacles only attach to the surfaces after it has been inspected by sensors linked to a nerve system in the barnacles. It has also been shown that the nervous system can be blocked by using an anti-neurone called catemine which seems to be very effective. 
However, the challenge is not to find a low toxic agent, but rather to put it into a long lasting paint. So far, it seems that it is only paint containing tin that can form a matrix of molecules that is scraped of slowly enough, layer by layer.

Another promising solution are repellent micro-texture surfaces. This technique has proven to be very efficient and has shown to block bio-fouling by up to $98 \%$ in tests.

The conclusions are:

- Except for silicones there are yet no non-toxic anti-fouling coatings on the market

- There seem to be good possibilities in "smart" coatings like repellent surfaces

- We need more knowledge about the fouling process.

\section{Summary of discussions}

The questions to be discussed were:

- What should be included in a Life Cycle Inventory of the fishing activity?

- Is it possible and if so- How can that be done?

\section{Group1:}

The discussions were started with a 'brain storming' session. A list of all things to include in a seafood LCA inventory was made and also a list of the major environmental effects caused by fishery was included.

The members of the group agreed that the following inventory data from fishery are important to include in an LCA of seafood:

- discards

- by-catches

- lost fishing gear

- seafloor disturbance

- anti-fouling agents

- cleaning

- garbage

- offal

- oil spills

Some of these data, e.g. oil spills, could be included in the impact categories normally included in an LCA while others require new impact categories. Examples of already existing impact categories are eutrophication caused by discards and eco-toxicity affected by anti-fouling agents. Other environmental impacts that need to be taken into account are:

- Mortality of target species, both decrease in production potential and ecosystem effects

- Mortality of non-target species

- Physical impact of the seafloor

- Working environment

- Animal welfare 
There is no simple way of characterising the inventory data into the impact categories listed above. It is however a good start for further investigations and discussions of how to include important parameters in an LCA of seafood.

\section{Group II:}

Took a different approach to the questions and focused more on the how than what. The group discussed the results of the different subjects of the workshop. The environmental aspects of fishery that should be included in the inventory phase were:

\begin{tabular}{|c|c|c|}
\hline $\begin{array}{l}\text { Environmental } \\
\text { aspect }\end{array}$ & "Units" & Comment \\
\hline $\begin{array}{l}\text { Discard of commercially } \\
\text { utilised species }\end{array}$ & $\begin{array}{l}\text { No. of fish }+ \text { economic } \\
\text { value }\end{array}$ & $\begin{array}{l}\text { Numbers of fish more crucial than } \mathrm{kg} \text { of discards, } \\
\text { economic value gives an idea of what is lost in economic } \\
\text { terms } \\
\text { The level of discard assessment is decided by the purpose } \\
\text { of the LCA. Especially sensitive or threatened species } \\
\text { should be assessed. }\end{array}$ \\
\hline $\begin{array}{l}\text { Discard of species not } \\
\text { commercially used }\end{array}$ & No. of fish & $\begin{array}{l}\text { Numbers of fish more crucial than kg of discards. The level } \\
\text { of discard assessment is decided by the purpose of the } \\
\text { LCA. Especially sensitive or threatened species should be } \\
\text { assessed. }\end{array}$ \\
\hline Target fishing intensity & $\begin{array}{l}\text { Mortality/ } \\
\text { Assessed stock size or } \\
\text { Production }\end{array}$ & \\
\hline Effects on other species & & $\begin{array}{l}\text { We decided that it is not feasible to quantify these effects } \\
\text { in the case of a single fishery at this moment, therefore } \\
\text { these effects will be described qualitatively }\end{array}$ \\
\hline$\underset{\text { Emissions }}{\longrightarrow}$ & $\stackrel{\mathrm{MJ} / \mathrm{kg} \text { of target }}{\longrightarrow} \mathrm{g} / \mathrm{kg}$ target & $\begin{array}{l}\text { Easy to measure but hard to find data, fishermen are the } \\
\text { best source of information if there is not a good record at } \\
\text { authorities, e.g. dealing with the tax subsidies }\end{array}$ \\
\hline \multirow[t]{2}{*}{ Seafloor impact } & $\begin{array}{l}\text { Proportion of } \\
\text { hardbottom impacted }+ \\
\text { severeness indicatior }\end{array}$ & $\begin{array}{l}\text { Severeness indicator can be determined either by the } \\
\text { impact on biodiversity, by the recovery time of the } \\
\text { ecosystem or by the presence or non-presence of some } \\
\text { indicator species. (Important whether impact is in new } \\
\text { areas or in already impacted) }\end{array}$ \\
\hline & $\begin{array}{l}\text { Proportion of } \\
\text { softbottom impacted }+ \\
\text { severeness indicator }\end{array}$ & $\begin{array}{l}\text { Severeness indicator can be determined either by the } \\
\text { impact on biodiversity, by the recovery time of the } \\
\text { ecosystem or by the presence or non-presence of some } \\
\text { indicator species (Important whether impact is in new } \\
\text { areas or in already impacted) }\end{array}$ \\
\hline Marine pollution & $\begin{array}{l}\mathrm{mg} \text { of anti-fouling } \\
\text { substances } \\
\text { targeteased } / \mathrm{kg}\end{array}$ & $\begin{array}{l}\text { We need to look more into literature of toxic effects of the } \\
\text { substances to be able to characterise them }\end{array}$ \\
\hline
\end{tabular}




\subsection{Workshop 3: Trondheim, November 22-23, 2001}

Energy use and utilization of the seafood catches (organised by Kristin Hassel and Harald Ellingsen)

Participants:

Kristin Hassel

SINTEF

Norway

Harald Ellingsen

SINTEF

Norway

Mikkel Thrane

Aalborg University

Denmark

Erling Larsen

DFU

Denmark

Berit Mattsson

SIK

Sweden

Friederike Ziegler

SIK

Sweden

Frans Silvenius

FGFRI

Finland

Helga R. Eyjólfsdóttir

Icelandic Fisheries Laboratories

Iceland

Invited speakers:

Snorre Angell

SINTEF

Norway

Stig Jansson

SINTEF

Norway

Tommas Leth

DTI

Denmark

Erik Olesen

Hoejmarklaboratoriet

Denmark

\section{Summary of presentations}

\section{Kristin Hassel: Investigations of the energy use within fisheries}

SINTEF has over the years collected data for energy consumption within the Norwegian fisheries from various sources. There is however little data available for the direct fuel consumption of the fleet. What is available is cost data collected by the Directorate of Fisheries. Calculations are therefore not based on direct data concerning fuel consumption, but on estimates based on financial figures from the Directorate, combined with data on fuel prices for the year concerned. These fuel prices have been obtained from various sources, such as oil and shipping companies.

The process of transforming reported costs into exact consumption in litres is a complex one, as the basic fuel price varies during the course of the year as well as from one vessel owner to another, as a result of differences in purchasing agreements. This is thus a possible source of error in the available material, as it is difficult to survey the exact prices that individual vessel owners have actually paid for their fuel.

Normally the energy consumption is larger for active fishing gear than for the passive ones. According to the registrations bottom trawling use around 0,5 to $0,8 \mathrm{~kg}$ fuel per $\mathrm{kg}$ of fish while long-liners use around $0,3 \mathrm{~kg}$ fuel per $\mathrm{kg}$ of fish. Pelagic trawling and 
purse net seining for herring and blue whiting are however rather energy effective with an energy usage of around $0,1 \mathrm{~kg}$ fuel per $\mathrm{kg}$ of fish.

The stock size has a major influence of the energy use per $\mathrm{kg}$ of fish, which is another good reason for good stock management. The tendency right now is that the fish stocks decrease and the fuel use per $\mathrm{kg}$ of seafood increases.

By following the seafood chain from the moment the fish is caught until it ends up at the dinner table, the overall environmental impact can be calculated. Several studies have concluded that the overall impact which could be assessed quantitatively is dominated by the use of fossil energy and that the overall energy use is dominated by the contribution from the catching phase (Cristensen and Ritter, 2000, Ziegler, 2001 and Aanondsen, 1997). It follows that it should be a rational strategy to take measures to improve the consumption rate during the catching phase.

This is the main background for the development of a computer based tool at SINTEF for calculation of energy consumption for fishing vessels. So far the tool is developed as a prototype version and is to be used during the early design phase. This tool has been developed as part of several research projects funded by both the Research Council of Norway and by the EU. The tool is based on the LCA methodology and further development is planned to introduce also calculation of environmental effects when comparing various conceptual solutions. Preliminary calculations show that there are technical measures that could be taken in the design phase to improve energy efficiency such as hull design, machinery configuration and design of propellers.

\section{Stig Jansson: Production of by-products on-board in the ocean-going fleet}

Often the utilization of the fish caught is quite low and better utilization would improve both the environmental and economical efficiency of the seafood production chain. One way of achieving this is to use by-products. During the period 1991-1999 the utilization of by-products has increased by $100 \%$.

The estimated total amount of by-products generated in the Norwegian fisheries was 621000 tonnes in year 2000 of which 476000 tonnes were utilized and the rest was dumped into the sea (Bekkevold, 2001). Dumping is permitted offshore but prohibited in coastal zones. To day by-products are mainly utilized as fish meal, ensilage and furbearing animal food. Only $10 \%$ ends up as high value products as human food, health foods and bio chemicals. These $10 \%$ contribute however to $50 \%$ of the value added.

In the traditional fisheries most of the fish were taken care of and used as cod-liver oil, food, medicine and even for clothing and as fertilizer. Modern fishing vessels are highly specialised and do seldom have the flexibility required to take care of the whole fish. Alternative products need dedicated process equipment, stowage holds etc. Such possibilities may however be a part of the design basis for new vessels in the future.

Availability of ultra fresh raw materials, no double freezing and surplus energy from the main engine that can be utilized for processing, drying etc. are arguments for producing by products on board. These will all contribute to the environmental accounts in a positive way. There are already good examples of trawlers having increased their profit by taking better care of the by-products by introducing improved sorting and logistic routines on board. 
Some by-products can be sold intact for human consumption, others can be used as protein source in animal production and fish oil can be extracted. According to a year 2010 forecast, the Norwegian fish farming industry will need 955000 tons of fish oil. This is expected to be a main challenge to this industry.

By-products can further be used as high value ingredients for human food, animal feed, pharmaceutical industry etc. The dominant marked is USA, Europe and Japan. The marked for marine based nutrients as functional foods, additive diet products, personal hygienic articles etc. passed USD 44,5 billion in the U. S. in 1999 and this is fast growing. The demand for marine protein sources has further increased after the BSE crisis.

One important aspect of better utilization of the fish caught is that the quota system sets a limit to the total catch and that utilization of by-products means added value within the existing limits.

\section{Snorre Angell: Fishing gear and size selectivity}

To avoid unwanted environmental effects, government measures have been introduced concerning the selectivity of fishing gear. Such measures include banning of, or restriction of, certain types of gear, introduction of minimum mesh sizes or the mandatory use of some sort of escape device to prevent non-target species/sizes from being caught. By-catches are unwanted for biological as well as for economic and practical reasons. To catch only targeted species of the desired size might need the implementation of several measures at the same time. If species are separated in time and space, only the task of size selection remains. If the species appear simultaneously in the same location, one might focus on differences in behaviour, and proper size selection at the same time becomes a very complex task.

Catching of undersized fish can be effectively prevented by means of mesh size when using gill nets and to some degree by using certain hook and bait sizes in the long-lining fisheries. Mesh selection and use of net panels are traditional means to sort out fish from trawls, for size as well as for species. However, by changing the rigging of the trawl, it is possible for the fishermen to manipulate the selection properties of the gear. Diamond-mesh cod ends may not serve the basic intentions of improved or altered selectivity. Studies show that there are many variables that influence cod endselectivity, where one of the most important is the reduction in mesh openings as the cod end catch increases (Engås et al., 1989, Larsen et. al. 1993). Along with other undesirable properties of mesh selection, this has led to a change of focus in selection research in recent years, to the use of selection grids.

A selection grid may be used in two basic modes: 1) preventing entry of fish or other animals exceeding a certain size from entering the cod end, and 2) letting undersized fish escape easily from the cod end.

The first known selection grid used in commercial fisheries was the so called TED (Turtle Excluder Device), a grid used in the Gulf of Mexico to sort out turtles from trawling of fish and shrimps. In Europe the "Nordmoere Grid" used for sorting fish from shrimps, is the first grid required by legislation (Isaksen et. al. 1991). In both these cases different species are sorted out by using size differences. 
The most used selection grid in Norway is the Sort-X grid as described by Larsen et al (1993). The sorting grids replace a part of the upper panel in the extension piece of the trawl, i.e. the tubular section between the belly and the cod end. The grids are made of stainless steel and consist of three sections linked together. Two separate grids with fixed bar distance are connected to a polyvinylchloride canvas-covered steel frame, the main function of which is to guide escaping fish away from the trawl and to keep the system balanced during operation. The system weight is about $90 \mathrm{~kg}$ (in air) and neutral buoyancy is achieved with plastic floats. Once in the sea, the system opens and is kept in a steady position by using chains. The angle of attack is theoretically close to $25^{\circ}$ in the first part of the system.

The most recent development is the Flexigrid, consisting of two grids (Angell, 1999). The two grids are constructed from flexible nylon rods connected by rubber spacebars, keeping the rods at a constant spacing suitable for the intended fishery. The grids are mounted in the extension piece of the trawl, one in the bottom part sloping upwards, allowing fish to escape downwards. The other is mounted in the upper part of the extension, sloping downwards, allowing fish to escape through the top. Both the spacebars and the rods are flexible enough to be wound on a net drum, and when in operation, the rods are kept in position with accuracy that ensures satisfactory size selection.

There are however experiences both on the positive and negative side when it comes to use of the grids so far. The Norwegian experience in this matter corresponds well with reports from other fisheries. In most fisheries where grids have been introduced, fishermen have initially complained that they are unwieldy, unpractical and cause the loss of commercial species. Yet, the use of the grids has subsequently become a success. In some shrimp fisheries which were threatened with closure due to excessive levels of discarding, the introduction of grids has allowed these fisheries to stay open (Anon., 1998).

More focus on selective and environmental friendly fishing gear is expected in the future. Fishermen are interested because of the quota system be increasingly dependent on better selectivity devices, and the consumers in the food market will require documentation that the fish has been captured in an environmentally friendly way. As a consequence, selection grids and other similar devices will be further developed and refined to achieve a more precise fishery where only the targeted species and sizes are caught. Improved knowledge about fish behaviour combined with technological skills in design, development and testing are necessary prerequisites for achieving such a goal.

Fish quality is also an important aspect since quality losses directly affects the environmental performance of a fishery and better quality gives a higher price. With Danish and Scottish seine as well as long-liners generally the fish quality is better than for trawls. Time is vital for gillnet fishing since the quality deteriorates when the fish is stuck in a net for a long time. 


\section{Tommas Leth, Erling Larsen and Erik Olesen: Danish LCA project on farmed rainbow trout}

Tommas Leth introduced for a discussion by presenting the strategy and the methodical basis for a Danish LCA program regarding farming of rainbow trout. The programme covers the complete chain from feed production until the fish lies on dinner table. Erling Larsen and Erik Olesen presented some preliminary results from a project within the same programme where use of sandeel as trout feed was studied. A process chain was studied including catching of sandeel, production of sandeel meal and oil, processing of fish feed, trout farming, trout processing and logistics. The work includes detection of process, energy and mass flow and system boundaries etc. for production of one $\mathrm{kg}$ of trout. Results were presented in so called MEKA sheets (Materials, Energy, Chemicals and others).

\section{Referenser}

Angell S. 1999: Developing of a flexible selection system for cod trawl. Post-graduate thesis. The Norwegian Collage of Fisheries Science, University of Tromsø; SINTEF Fisheries and aquaculture, Trondheim. Augsut 199. 253 p. In Norwegian

Anon. 1998: The problem of discards in fisheries, STOA publication No. EP/IV/B/STOA/98/17/01, Megapesca Lda., Portugal

Bekkevold, S., 2001, Verdiskapingspotensiale for biproduktene - grunnlag for utvikling av en biomarin ingrediensindustri, presentation hold at "Nordisk konferanse om verdiskaping av biprodukter".

Cristensen P., Ritter E. 2000: Life cycle screening of pickled herring in jars, Department of Develpoment and Planning, Aalborg University, Denmark

Engås A., Isaksen B. and Valdemarsen J. W. 1989: Escape behaviour of fish in codends of trawl. In Proceedings of the Square Mesh Workshop held at the World Symposium on Fishing Gear and Fishing Vessel Design, St. John's Canada, November 1998. Ed. by A. Carr, Mass. Div. Mar. Fish., Boston

Isaksen B. and Larsen R. B. 1993: Size selectivity for shallow water shrimps using a rigid metal grid in the aft and top section of the trawl. Report of Institute of Marine Research, Bergen and The Norwegian College of Fishery Science, Tromsø, Norway

Larsen R. B. and Isaksen B. 1991: Size selectivity of rigid sorting grids in bottom trawls for Atlantic cod (Gadus morhua) and haddock (Melanogrammus aeglefinus). ICES Mar. Sci. Symp., 196: 178-182

SIK Document 141. 2001. LCA of Fish. First workshop. Organised at SIK Göteborg, Sweden. February 26-27.

SIK Document 145. 2001. LCA of Fish. Second workshop: Including fishery-related marine environmental impact in seafood LCAs. Organised at the North Sea Centre, Hirtshals, Denmark. August $15-17$.

Ziegler, F. 2001. Environmental Assessment of seafood with a life-cycle perspective, Licentiate Thesis, Department of Marine Ecology, Göteborg University and SIK, The Swedish Institute for Food and Biotechnology, Göteborg, Sverige, December 2001, ISBN 91-7290-216-7, SIK Report 689.

Aanondsen S. Aa. 1997: Livsløpsanalyser for beregning av miljøpåvirkning brukt som verktøy ved prosjektering av skip (Life Cycle Asessment (LCA) as a tool in ship design), Hovedoppgave, Institutt for marin prosjektering, NTNU 
9.4 Workshop 4: Reykjavík, March 21-22, 2002

Seafood processing and quality of fish products (organised by Helga Eyjolfsdottir and Eva Yngvadottir)

Participants:

Jens Munk

Mikkel Thrane

Harald Ellingsen

Staffan Larsson

Frans Silvenius

Friederike Ziegler

Berit Mattsson

Halla Jónsdóttir

Bryndís Skúladóttir

Eva Yngvadóttir

Helga R. Eyjólfsdóttir

Invited speakers:

Peter Tyedmers

Kristín Ólafsdóttir

Jörundur Svavarsson

Emilía Martinsdóttir

Sigurjón Arason
DTI

Aalborg University

SINTEF

National Board of Fisheries

FGFRI

SIK

SIK

IceTec

Ice Tec

IFL

IFL

Dalhousie University

University of Iceland

University of Iceland

IFL

IFL
Canada

Iceland

Iceland

Iceland

Denmark

Denmark

Norway

Sweden

Finland

Sweden

Sweden

Iceland

Iceland

Iceland

Iceland

Iceland 


\section{Summary of presentations}

\section{Sigurjón Arason and Eva Yngvadóttir: Development of energy simulator for the fish industry - ORKUSPAR}

ORKUSPAR - The Energy Efficiency Improvement Simulator is the name of a project, co-ordinated by the Icelandic Fisheries Laboratories. The objective of this project is to develop an energy efficiency improvement simulator specifically aimed at ocean freight shipping and the fishing industry, both sea- and land based. The simulator will, hopefully, be an effective tool for the assessment and monitoring of envisaged energy efficiency measures.

The simulator will enable owners, management, designers and operators of the relevant facilities (fish processing- and freezing plants, ocean trawlers, container and other shipping) to quantify attainable energy efficiency improvements for energy use and environmental pathways in shipping and deep-sea fishing vessels (fish processing trawlers).

The software simulates economic and other benefits affected by diverse measures, intended for instance to decrease primary fossil fuel consumption, improve energy efficiency of processing systems, improve automatic control and monitoring of systems or decrease deleterious pollutant emissions. The primary goal is to decrease harmful gaseous emission into the atmosphere in a sustainable manner whilst trying to meet the targets set in Agenda 21 and subsequent Kyoto declarations.

\section{Peter Tyedmers: Estimating fuel inputs to North Atlantic Fisheries}

As part of the Sea Around Us project at the University of British Columbia, research was undertaken to quantify the fuel energy consumed by contemporary North Atlantic fisheries. Where possible, this included evaluating changes in direct fuel inputs to fisheries over time. Two distinct methods were employed in estimating both the total fuel consumption and the energy intensity of specific fisheries and fishing fleet sub-sets. The first method involved soliciting relevant data directly from fishing companies. The second technique combined estimates of the generic rates at which fishing vessels consume fuel in relation to their main engine horsepower, as derived from real-world vessel performance data, with detailed catch and fishing effort data. Ultimately, a total of 58 analyses were conducted, representing 54 distinct North Atlantic fisheries or fleet sub-sets. Based in five countries, these 54 fisheries together account for total annual landings, as of the late 1990's, of over 5.2 million live weight tonnes of fish and/or shellfish, and encompass a range of fishing gears, vessel sizes and primary target species. Moreover, for almost half of the fisheries analysed, time series estimates of energy intensity and total fuel consumption were possible for periods ranging up to 21 years. For the most recent years in which data were available, the results indicate that these 54 fisheries together consumed just over 1 billion litres of fuel annually. Amongst the 29 groundfish fisheries analysed, energy intensities ranged from a low of 230 litres/tonne to just over 2,700 litres/tonne. When taken together, however, these 29 fisheries experienced a mean energy intensity of about 510 litres/tonne of groundfish and associated bycatch species landed. In contrast, amongst the twelve fisheries targeting small pelagic species analysed, contemporary energy intensities ranged from 19 to 159 litres/tonne of fish landed and averaged just 62 litres/tonne. The single 
relatively small fishery for large pelagic species analysed experienced an energy intensity of 1,740 litres/tonne of tuna and swordfish landed. Amongst the invertebrate fisheries evaluated, the average energy intensity of the eight fisheries targeting shrimp was 918 litres/tonne, while the two scallop fisheries had an average energy intensity of just 347 litres/tonne landed, and the single crab fishery evaluated had an energy intensity of about 330 litres/tonne. Finally, the lone fishery for Norway lobster analysed, experienced an energy intensity of 1,025 litres/tonne of total landings.

\section{Harald Ellingsen: Energy use in the Norwegian fishing fleet and sustainable vessel technology and fleet structure}

\section{Introduction}

In recent years, efforts have been made at Marintek AS and SINTEF Fisheries and Aquaculture, to model the operation of individual vessels, as well as that of the codfishing fleet. This work has aimed at identifying indicators for the performance of different segments of the fleet, under a variety of external conditions. The cod fishing fleet consists of a number of segments or vessel groups representing different catching technologies and modes of operation. Changes in the fleet's boundary conditions, in the ocean environment as well as in the business environment, will have an impact on the operations and the output of the vessel groups to a varying degree, depending on the technology they use. The indicators are chosen to show the effect of variations in fish abundance, fish prices, fuel prices, interest levels and fish quotas on the output from the different fleet segments.

SINTEF Fisheries and Aquaculture is about to start up a strategic research institute program titled "Sustainable Vessel Technology and Fleet Structure". It aims at developing new expertise, new methodology and new tools within fishing vessel research. A further aim is to contribute to the advancement of a more sustainable fishing fleet. The programme will subsequently provide a basis for development within applied research with a wide industrial participation. Objectives are to develop:

- An environmental database for fishing vessels

- A reference platform for environmental assessment of fishing vessels

- Tools for early design of fishing vessels including assessment of life time environmental impacts

- Tools and methods for analysis of technological choices and effects on fleet level

- A methodology for establishing new design criteria resulting from future demands to sustainability

- New sustainable vessel concepts demonstrating practical use of the databases and design tools 


\section{Some comments on the results}

As part of the research project "Energy efficiency and pollution", energy use in various fishing methods are analysed based on data for the Norwegian cod fisheries from 1980 to 1999. The "fuel coefficient" expressed as the fuel consumption per unit of fish landed ( $\mathrm{kg}$ of fuel $/ \mathrm{kg}$ of fish) is a measure of the energy intensity in fishing. Round, ungutted fish is used as unit of fish. The results indicate that fresh fish trawling and factory trawling are the most energy consuming fishing methods while purse seine is most efficient.

Further the correlation between energy consumption and catch rates are analysed. Catch rates are defined as $\mathrm{kg}$ of fish caught per day at sea. These results show a strong reversed correlation between catch rates and energy use for trawling, strongest for factory trawling. For coastal fishing this correlation was rather weak.

Some sensitivity analyses are further performed in order to investigate the robustness of the various fishing methods with respect to external pressures, such as changes in the oil price, interest rate and fish prices. These external changes may be expressed by scenario descriptions. For each scenario the expected catch, income, energy cost, capital cost (including maintenance and insurance) and what is called "wage paying ability", WPA, are calculated. WPA is stipulated to represent the money available to the human resources engaged in the operation, including the vessel owner, after paying fuel bills, capital costs and other direct operating costs except wages. The WPA per kg fish landed is used as indicator to have a common measure for all fishing methods. Based on the data from the above referenced time-series, a model has been developed that calculates the effect the different future scenarios may have on fishing operations with different types of fishing gear. The results presented here indicate a high degree of sensitivity for trawling, both factory and fresh fish trawling for changes in energy price and interest rate while purse seining shows low sensitivity in both cases. They also indicate that the choice of catching technology has a profound effect on the environment as well as robustness of the fishing fleet with respect to changes in the external conditions.

\section{Friederike Ziegler: Environmental assessment of seafood with a life cycle perspective}

In the presented research project, environmental aspects connected to fishery have been quantified for a specific case, the Swedish cod fishery in the Baltic Sea. The aim was to demonstrate how the different types of environmental impact can be quantified in a case study. It was also a goal to present environmental data for the entire life-cycle of a seafood product. The method used for environmental assessment was Life Cycle Assessment (LCA), which assesses resource use and emissions throughout the life cycle of a product. The Baltic cod was followed from the fishery through a processing industry where it is filleted, frozen and packaged to consumer-packed blocks of $400 \mathrm{~g}$. From there, the product was followed to wholesalers, retailers and finally to the household. Resource use and emissions caused throughout the life cycle is included in the assessment.

Results showed that fishery dominates all investigated environmental impact categories (Global Warming Potential, Eutrophication Potential, Acidification Potential, Aquatic Ecotoxicity, Photochemical Ozone Creation Potential). Fishery is responsible for $75 \%$ of the total energy consumption in the life cycle of the product, mainly due to onboard diesel consumption. The difference between gillnet and trawl fishery is considerable, 
because the fuel consumption in trawl fishery is higher than in gillnet fishery. A separate study concerning fuel consumption and emissions in the Swedish cod fishery was presented. Following fishery, the car transport home from the retail store affects the categories global warming, acidification, photochemical ozone formation and ecotoxicity most. The consumer phase was also shown to be important. Preparation at home contributes to impact categories global warming, acidification and photochemical ozone formation, mainly due to the electricity consumption of the oven. The total amount of discarded fish was shown to be around $50 \mathrm{~g}$ per cod block and discards mainly consisted in under-sized cod and flounder. Cod stocks in the Baltic are, at present, not fished on a sustainable basis. The seafloor area impacted by trawls was determined to be around $700 \mathrm{~m}^{2}$, corresponding to a square of $27 * 27 \mathrm{~m}$, per average cod block through analysis of fishing effort data in a GIS (Geographical Information System).

Because of the importance of fishery for the overall results of the LCA, many improvement options can be found in the fishery phase of the life cycle. Sound management of the fished stocks is a prerequisite for an environmentally sustainable fishery. Education of fishermen in fuel-saving vessel operation and a gradual exchange to modern engine technology as well as development of more flexible gear are some measures that would lead to decreased fuel consumption and emissions. Due to the dominance of fishery in the overall results, one of the most important environmental issues, once the fish has been landed, is that it is used efficiently, minimising product loss and maintaining high quality throughout the production chain. In order to keep high product quality it is important that the fish is handled and cooled properly from the moment of catching it. The environmental burden occurring because of product loss has to be added to the product which is actually used for its purpose, as human food. Therefore, the most important measure to decrease the overall environmental impact of the product can be to decrease product losses.

\section{Bryndís Skuladottír, Halla Jónsdóttir, Helga Eyjólfsdóttir and Eva Yngvadóttir: LCA of Icelandic cod products, the present status}

A LCA of cod is conducted by the Icelandic Fisheries Laboratories (IFL) and Technological Institute of Iceland (IceTec). The collection of information is done in cooperation with the following parties: The fishery Haraldur Böðvarsson Ltd on data for the fishing vessel; the transportation company Samskip on truck transport in Iceland and freighter transport to UK; the seafood distributor SÍF on UK transport chain and; several other parties such as producers of paint, cooling agents and packaging and other companies and specialists for verifying data, comparison and general description of the processes. The work has so far included decision on the choice of functional unit, the designing of a flow chart, the choice of boundaries and allocation, the collection of information and the building of the process in the LCA software program SimaPro.

A $9 \mathrm{~kg}$ frozen cod fillet package was chosen as the functional unit. The fillets were with bones but without skin and are processed on board a freezing trawler. The rationale for this choice is that this is a valuable and important product for the Icelandic economy. Less than $50 \%$ of the fish that is caught is used in the fillet production, the rest is usually used in several by-products.

Boundaries were chosen as not to include production of trucks, trawlers, fishing gear, etc. Mass allocation was done towards other species. Some evaluation of the consistency of the data has been made, as well as evaluation of the accuracy and the 
results of using average data mixed with specific data. The collection of data has not been completed and preliminary results from inventory analysis and impact assessment are not ready to be published yet. General discussion on whether to include the cod itself as an input from nature has taken place, along with evaluation of different weighting methods.

\section{Frans Silvenius: LCA of rainbow trout cultivation}

This work, which is methodologically based on life cycle assessment, is beginning from the extraction of raw materials and ending with the delivery of gutted fish to retailers or to further processing. The assessment includes the life cycle impacts of technically different production methods as well as methods for emission reduction. The environmental impacts of cultivated rainbow trout are compared with the impacts of Norwegian cultivated salmon, Baltic herring and pig and cattle meat production in Finland.

Atmospheric emissions have only a minor contribution to the total environmental impacts caused by the production of Finnish rainbow trout. Phosphorus and nitrogen emissions from the cultivation into waters cause the strongest environmental impacts. The main reason is that rainbow trout production cause greater part of nitrogen and phosphorus loads in Finland than of airborne emissions in Finland.

No significant differences were found between the emissions caused by the production of Norwegian cultivated salmon and Finnish rainbow trout, but the Norwegian salmon causes less eutrophication than the Finnish rainbow trout. On the other hand, salmon lice and escaping cultivated salmon, which is giving rise to a genetic threat to the natural salmon populations, are regarded as major problems in Norway - not eutrophication. In the cultivation of Finnish rainbow trout, escapes are not considered a problem.

When comparing the emissions originating from pig and cattle meat production, eutrophying discharges, mainly from feed production, appear to be the environmentally most significant emissions. Atmospheric methane and ammonium emissions have also significant environmental impacts. However, it was not possible to make comparisons between the total impacts of the fish and meat products in this work because of lack of adequate assessment methods for some impacts. Comparison is difficult, because fish farming affects aquatic ecosystems, whereas pig and cattle meat production have impacts particularly on terrestrial ecosystems. The fishing of Baltic herring turned out to be most environmentally friendly of the investigated products and even beneficial to the environment, because the nutrients in Baltic Sea decrease due to the fishing of Baltic herring.

The reduction of nutrient emissions from fish cultivation is the key factor in developing the ecological and social sustainability of rainbow trout production. By using new, environmentally friendly feeds it is possible to reduce the environmental impact of fish farming. The increased feed efficiency reduces both nutrient and organic loads. By using a feed containing soya protein, or other similar alternative protein sources, it is possible to decrease the current level of nitrogen and phosphorus load by half. The use of the soy meal means about 8 cents $(0.084 €)$ additional cost per $\mathrm{kg}$ fish produced. This is reasonable compared to the fish farmers' price (3.2€ in 1999), whereas the technical measures to reduce emissions from fish farms cause higher costs - up to $1-3 €$ per $\mathrm{kg}$ 
fish produced. In addition, technical measures significantly reduce the phosphorus load but have only minor effects on nitrogen. For this reason, the measures are more suitable for inland water areas. Phosphorus is the main limiting nutrient in inland waters of Finland.

Various needs for further research were identified during this work. The data should also include other important environmental issues such as effects of the fishing of feed fishes. The impact assessment method should be developed for assessing new impact categories. Furthermore, the method should be capable of assessing regional effects due to domestic emissions.

Socio-economic values were studied also in the study in addition to environmental issues. The parameters were the financial value of fish products, income effects and employment. We had, however, difficulties producing comparable socio-economic values for the production of pig and cattle meat due to the subsidisation of agriculture. Thus, it is not possible to prioritise the use of rainbow trout, pig and cattle from the ecoefficiency point of view.

\section{Eva Yngvadóttir: Heavy metals in marine biota in Icelandic waters}

A monitoring program, AMSUM, has been running annually at IFL since 1989. The goal of this monitoring programme is:

1. To gather information on the current status of the ocean around Iceland

2. To determine if human health is in danger by consuming fish products

3. To assess potential danger to marine life caused by contaminants.

The main role of the IFL in the program has been gathering data from Icelandic fisheries. Each year, samples of cod (Gadus morhua), dab (Limanda limanda) and blue mussel (Mytilus edulis) are taken at different locations with standardised methods. These species are considered to be representative of different habitats. The heavy metals lead, cadmium, copper, zinc, arsenic and selenium are measured in cod and dab liver and in mussel tissue. Mercury is measured in the muscle of cod, dab and mussel tissue.

The main conclusion for cod from Icelandic fishing grounds is that concentration of heavy metals is low compared to other northern locations. The only exception is cadmium, which is probably of volcanic origin, reflecting natural background values. Research of moss around the active volcanic zone show high levels of cadmium and supports this suggestion. Also, there are no anthropogenic sources at hand where the levels of cadmium are high. No trend can be observed in the concentration of heavy metals, but annual and seasonal variation is significant. The unique characteristics of the Icelandic environment in terms of oceanography, meteorology, geology and biology make determinations of natural background values critical. A simple comparison with values from neighbouring countries can therefore be misleading. 


\section{Reference}

Davíð Egilsson et al., 1999. Mælingar á mengandi efnum á og við Ísland. Niðurstöður vöktunarmælinga. Starfshópur um mengunarmælingar, mars 1999, Reykjavík. 138 pages.

\section{Kristín Ólafsdóttir: Organochlorine pollution in Icelandic waters}

The levels of persistent organochlorine pollutants (POPs) have been monitored in the marine environment around Iceland for several years. These manmade chemicals can undergo long-range transport either via the atmosphere or ocean currents and are ubiquitous even in the most remote areas of the globe. There has been very little local use of organochlorine pesticides in Iceland, but PCBs and HCB, which are industrial chemicals, can originate at least partly from local sources. The organochlorines are believed to disrupt endocrine functions in animals and humans and can thus affect their development, fertility and immune system. POPs are very stable, lipophilic chemicals that can often bioaccumulate to a great extent, reaching possible toxic levels at the end of the food chain. We have analyzed samples from blue mussels (Mytilus edulis) collected along the coast of Iceland; from dab (Limanda limanda) liver and cod (Gadus morhua) liver, collected in the deep ocean around Iceland.

The results indicate very little organochlorine pollution in the blue mussel; most chemicals analyzed are at or below detection limits. The levels in dab and cod are also quite low and comparable to levels found around the Faroe Islands and the NW-coast of Norway. PCBs are the most abundant chemical group in these species with the sum of 7PCBs in the range of $20-100 \mu \mathrm{g} / \mathrm{kg}$ liver. Very little can be said about time trends, since the data is very variable. However, the levels indicate lower pollution in the NW area and higher pollution in the SW area around Iceland.

\section{Peter Tyedmers: All salmon are not created equal: Measuring the biophysical costs of salmon fishing and farming in British Columbia, Canada}

Technologies play a critical role in mediating the impact of the human enterprise on the ecosphere. Consequently, the adoption of more biophysically efficient technologies is essential if the sustainability of the human enterprise is to improve as populations and per capita consumption demands increase. Within this context, the biophysical efficiency of two salmon production technology systems were analysed and compared using ecological footprint and energy analysis. The two systems evaluated are the vessel-based commercial salmon fishery and the salmon farming industry, as both exist in British Columbia, Canada. In addition, the relative efficiency of the three harvesting technologies employed within the commercial fishery were also evaluated. The ecological footprint analyses entailed quantifying the marine and terrestrial ecosystem support areas needed to grow salmon, sustain labour inputs, and assimilate $\mathrm{CO}_{2}$ equivalent to the greenhouse gases that result from industrial energy and material inputs. The energy analyses focussed exclusively on the direct and indirect industrial energy inputs to both systems. The results of both the ecological footprint and energy analyses indicate that salmon farming is the least biophysically efficient, and hence least sustainable system for producing salmon currently operating in British Columbia. On a species-specific basis, farmed chinook salmon (Oncorhynchus tshawytscha) appropriated the largest total area of ecosystem support at $16 \mathrm{ha} /$ tonne. This was 
followed by farmed Atlantic salmon (Salmo salar) at 12.7 ha/tonne, and commercially caught chinook and coho salmon (Oncorhynchus kisutch) at $11 \mathrm{ha} /$ tonne and 10.2 ha/tonne, respectively. Commercially caught sockeye (Oncorhynchus nerka), chum (Oncorhynchus keta), and pink salmon (Oncorhynchus gorbuscha) had the smallest total ecological footprints at 5.7, 5.2 and $5 \mathrm{ha} /$ tonne, respectively. Results of the energy analyses followed a similar pattern. Farmed chinook salmon required a total fossil fuel equivalent industrial energy input of about $117 \mathrm{GJ} /$ tonne while at the other extreme, total energy inputs to commercially harvested pink salmon amounted to only 22 GJ/tonne. Within both systems, however, opportunities exist to improve the biophysical efficiency of salmon production. Finally, amongst the three commercial fishing technologies evaluated, purse seining was approximately twice as efficient at harvesting an average tonne of salmon as were either gillnetting or trolling.

\section{Summary of discussions}

Before the participants arrived they were given some questions to consider for the workshop. The questions were:

1. How is the quality of fish taken into consideration in LCA studies ?

2. How is ISO 14000 series used in LCA studies?

3. How are evaluation methods in LCA chosen/used/changed?

4. How are levels of contaminants (metals, POP's) in the marine environment (biota, sea, sediment) validated in LCA studies?

A brief summary from the discussions is presented below:

\section{How can quality of fish be taken into consideration in LCA studies?}

Fish is a biological raw material, which contains proteins, water, vitamins, minerals etc. Therefore, the quality regarding e.g. the shelf life is of great importance. The shelf life can differ a lot depending on the storage temperature, the size of the fish, fishing gear etc. Any discussion of LCA should therefore take these factors into account. There were two aspects discussed about how quality affects LCA studies of fish and fish products. The first one concerned the definition of the functional unit and the second one concerns the use of data from different sources (for example, different fishing gear, handling and storing the raw material etc.). What is the function of the functional unit? If the goal of the LCA study is to assess the environmental impact of a certain process, the evaluation of the product quality from that process is not taken into consideration. However, using LCA in comparison, it has to be of great importance to make sure that the functional unit does not differ in quality. So it would be a good thing to know about all the "hot spots" in a process and be able to identify whether quality aspects are of importance. Finally, it can be said that quality is important and is directly related to the objectives of the LCA study and methods to quantify quality (e.g. QIM) could be very useful for seafood LCA practitioners. 


\section{How is ISO 14000 standard used in LCA studies?}

Today there are published several ISO standards within the 14000-series. They are guidelines for the researcher going through the different stages in LCA analysis and evaluation parts but they do not give any detailed recommendations for application of LCA on different types of products. These standards can be of good help when structuring an LCA report.

\section{How are evaluation methods in LCA chosen/used/changed?}

There are several valuation methods available to day that emphasise on different environmental objectives. The evaluation methods used today in software tools like Sima Pro focuses on process industries like paper, polymer etc. Again, fish is a biological raw material and there is no valuation method available today which fully takes this aspect into account. However, some researchers working on biological material have used different evaluation methods and modified them (like EDIP). That raises the question: How far should researchers go in the evaluation process? Sweden has chosen to do only the characterisation, but no weighting and normalisation, while both Iceland and Denmark have tried to normalise.

\section{How are levels of contaminants in the marine environment valuated in LCA studies?}

The discussion group agreed that it is difficult to evaluate levels of contaminants in the environment in LCA-studies because there are different levels of contaminants in different species at different locations. Local effects need to be taken into consideration; furthermore, it is difficult to assess global effects. 


\subsection{Workshop 5: Roskilde, November 4-5, 2002}

Dissemination of network results (organised by Erling Larsen and Berit Mattsson)

Project participants:

$\begin{array}{lll}\text { Berit Mattsson } & \text { SIK } & \text { Sweden } \\ \text { Helga R. Eyjólfsdóttir } & \text { IFL } & \text { Iceland } \\ \text { Harald Ellingsen } & \text { SINTEF } & \text { Norway } \\ \text { Staffan Larsson } & \text { National Board of Fisheries } & \text { Sweden } \\ \text { Frans Silvenius } & \text { FGFRI } & \text { Finland } \\ \text { Berit Mattsson } & \text { SIK } & \text { Sweden } \\ \text { Erling Larsen } & \text { DFU } & \text { Denmark } \\ \text { Per Christensen } & \text { Aalborg University } & \text { Denmark }\end{array}$

Workshop participants:

Elias Papatryphon

INRA

France

Jan Atle Liodden

Ostfold Research Foundation

Norway

Karin Ring

National Board of Fisheries

Sweden

Jens Munk

DTI

Denmark

Heidi Andersen

Hojmarklaboratoriet

Denmark

Thomas Ohlsson

SIK

Sweden

Tam Mungkung

Centre for Environmental Strategy

UK

Aslak Kristiansen

Norges fiskarlag

Norway

Invited speakers:

Bo Weidema

2.-0 LCA consultants

Denmark

Peter Jessen

Biomar

Denmark

Hans Martin Norberg

Fiskeriforskning

Norway

Bengt Ahlström

Abba Seafood

Sweden

Lone Rosing

Cerealia Bakeries

Denmark

During the first day of the workshop the project participants presented and discussed their work on different LCA related issues. 


\section{Summary of presentations}

\section{Bo Weidema: Database format ISO 14048}

Bo Weidema stressed the importance of using the proposed terminology in order to avoid misunderstandings when database data is used by others.

\section{Berit Mattsson: Network results}

The network coordinator summarized the results of the project. Experts of different fishery related environmental impacts have shared their knowledge during the workshops in this project and they have discussed it with the project participants who are primarily LCA experts. Issues like seafloor effects of fishery, mortality of target and non-target species have been discussed. The results are thoroughly described elsewhere in this report (see discussion and summary)

\section{Per Christensen: LCA on pelagic fish and perspectives for demersal fish}

Per Christensen, Aalborg University described the pioneering work of his institute in the area of LCA of fish products: a study of pickled herring packed in a glass jar. The results underline the importance of fishery. The use of toxic paints (TBT, copper) for anti-fouling made a major contribution to the total environmental impact of the product. Per also addressed the need for further development of the LCA methodology for LCA of fish products and, even more, he stressed the need for better validation of LCA studies.

\section{Lone Rosing: LCA as a decision making tool in the food industry}

Lone Rosing from Cerealia Bakeries shared her experience of LCA as a decision making tool in the food industry. Cerealia has carried out LCA studies with the objective to learn more about the environmental impact of their products. Typically for food products the primary production contributes significantly to the total environmental impact. However, for bread also the bakery and packaging systems are important. The LCA studies have shown the decision makers of the company the most urgent needs for improvement of the environmental performance, e.g. energy use in the bakeries. Cerealia Bakeries have chosen to make the LCA results public which means that this information is provided to interested consumers.

\section{Harald Ellingsen: Environmental management-LCA in Norwegian salmon farming}

Harald Ellingsen, SINTEF presented LCA results from a study of farmed salmon. Norway is the leading country in salmon production ( $45 \%$ of the world production). The aquaculture production in Norway (approximately 500000 tonnes in the year 2000) is predicted to increase significantly in the future. The environmental impact of aquaculture shows similarities to animal production of farms: feed production is a major contributor to the environmental impact and medication means that toxic substances are released to the environment. There are also other problems like the risk of escape which has an impact on the wild salmon stocks. Eutrophication by nutrient emissions from 
aquaculture facilities (excess feed and excretion products) can also be a problem if fish farms are situated in areas with limited water exchange. Despite the problems, aquaculture is of great interest: with better utilisation of by-products and feed produced of fish that are not suited directly for human consumption, the environmental performance can be improved. The biological efficiency may also be improved if feed is produced of catch on a lower food chain level.

\section{Staffan Larsson: Possibilities for Life Cycle Assessment to improve fisheries management}

Staffan Larsson, Swedish National Board of Fisheries shared his views on how LCA can provide information for the decision makers in fisheries management. Fishery management is complex and constantly questioned and debated. The challenge of the future is to manage limited resources for an expanding market. Presently too many vessels are catching too few fishes, and it is necessary to get a better balance between effort and stocks. A long term approach to conserve stocks and protect the environment is needed. A more holistic view and more knowledge of the chain from fishery to fork is needed. LCA can serve as an instrument to gain more knowledge about the environmental impact of choice of type of fishing gear, vessel, fishing grounds etc.

\section{Hans- Martin Norberg: Consumers and collective trademarks: Implications for green labelling}

Hans-Martin Norberg, Norwegian Institute of Fisheries and Aquaculture Research presented his work on collective trademarks. A collective trademark is a voluntary noncompany specific symbol, like green labelling. The purpose of collective trademarks is to communicate positive information about the product in order to give it added value. When a consumer evaluates a food product a lot of information has the potential to influence the choice, however only a few sources of information actually influence the choice. Norberg gave some examples of results from research in this area and it has been shown that the price is an important criteria for the choice of food products. Nevertheless, it has also been shown that organic production labelling is very wellknown and another important criteria.

Peter Jessen: A commercial company's choice to produce a certified product: eco-labelled feed for farmed fish

Peter Jessen, Biomar A/S described the fish feed industry. An average mill for fish feed produces 100000 tonnes per year and one production line produces 12-14 tonnes/hour. With such large units it is expensive to change product and the fish farmers want high and uniform quality of the feed. Biomar sells organic fish feed although the quantities are small and the demand very limited at the moment. It takes 10-12 hours of production stop to clean the production line and prepare it for production of organic fish feed. This means that the overhead cost is high as well as the raw material cost for organic feed.

Aquaculture causes eutrophication and one way to reduce these problems is to achieve a better match between feed and different types of animals. One example is that fish meal with a high $\mathrm{P}$-content could be used in pig production where $\mathrm{P}$ is normally added to the feed. 


\section{Erling Larsen and Helga Eyjolfsdottir: Two seafood LCA case studies}

Erling Larsen, DFU gave a presentation of the results of a Danish study of the environmental aspects of eco-labelled farmed fish and Helga Eyjolfsdottir, IFL presented results of an LCA study of Icelandic frozen cod. The workshop gave a good overview of the environmental impact of farmed and wild caught fish. It was also illustrated what type of result that can be yielded by LCA studies and how LCA results can be useful for environmental management in fishery management as well as in the fish industry. 



\section{Discussion and conclusions}

\subsection{Main results of the network}

The network has brought together the Nordic competence on LCA applied to seafood, which is pioneering this research field, as mentioned earlier. We have had the chance to get to know each others work in detail and exchange experiences from practical LCA work as well as discuss methodological issues which have arisen in the various national projects. Moreover, we have had the chance to invite speakers to talk about their specialities in areas where we felt that more knowledge is needed in order to be able to advance seafood LCA methodology. This increased knowledge was used to develop methods for some of the fishery-specific environmental impact categories and to suggest indicators for measuring the specific environmental impact of a fishing activity. Methodological development has thereby been more efficient than it otherwise would have been.

\subsection{Application of results and benefits for the Nordic seafood sector}

Today, there is still only a handful of seafood LCAs at hand, and their use by the seafood industry still lies somewhat in the future, but it is getting closer. Today it would be possible to perform a relatively complete LCA for a commercial seafood product with the aim of either improving production from an environmental point of view or to formulate eco-labelling criteria for that product. This was not possible a few years ago and the network has contributed considerably to the development of methodology in this area. Benefits from an application in the industry would be that Nordic seafood companies would take the lead in communicating environmental information to their customers. Such information is demanded increasingly by companies purchasing seafood products, as a part of their environmental management system. The information coming out from seafood LCAs can also be communicated to consumers through ecolabelling schemes. Growing awareness about environmental impact of food production in general and for seafood production in particular, has led to increased demand for ecolabelled products. Seafood companies who can provide this type of information about their raw materials and products have a competitive advantage. 


\subsection{Conclusions regarding methodology}

\section{System boundaries}

Seafood LCAs so far have generally started with production of supply materials such as fuel, anti-fouling paints, packaging material, fishing gear. The production of the fishing vessel as well as other capital goods is normally not included. It has been shown that the building of the fishing vessel does not contribute significantly to the life-cycle impact of a fishing vessel and other capital goods such as buildings and roads can be expected to contribute even less. Products are then followed during fishing, landing, transportation, processing, packaging, storage, wholesale, retail, cooking, consumption and waste treatment; depending on the life-cycle of the product. When a product takes many different ways after landing it was decided that it is preferable to follow the main product stream if a general study of the production is performed. A possibility is also to make different scenarios and evaluating the impact of different factors on the results as a kind of sensitivity analysis.

\section{Functional unit}

Especially in comparative studies of two or more products, the product quality should be considered when defining the functional unit. If the quality differs, the products are not exchangeable. Moreover, the amounts reaching the consumer after fishing the same amount e.g. with different gears might differ, because the product yield is different due to quality differences. This was considered as very important and tricky, as quality is difficult to measure/define objectively. However, it was suggested that the QIM method could be used for that purpose.

\section{Allocation}

In fisheries we always have to deal with by-catch that is landed in addition to the target catch. Approaches on how to account for these by-catches include expanding the system to investigate also a system only catching the target species, which is rarely possible, but preferable. Another approach is to divide the environmental burden between the main product (target catch) and by-product (by-catch) based on weight of the two fractions, so called mass allocation. A third way is to divide based on the economical value of the two fractions, reflecting the causes of the environmental burden. All three approaches have been used in the seafood LCAs prepared by the project participants. The group agreed upon that system expansion is the preferable alternative when possible. When target catch and by-catch have a similar economic value, mass allocation can be used (especially if the economical value is fluctuating) with good precision. Otherwise, e.g. in combined groundfish/crayfish (high-value) fisheries and in allocation between fillet (high-value) and fish waste (low-value), economical allocation is preferable. 


\section{Database format}

The group has decided that data documentation according to the developing database format ISO 14048 is the best for a common seafood LCA database.

\section{Weighting}

No consensus has been reached whether weighting/valuation and normalisation should be carried out or not. It may be case- and objective-dependent.

\section{Seafloor}

The group has agreed on that seafloor effects of fishing are an important issue and should be included in a seafood LCA. It can be assessed qualitatively by describing the type of habitat or marine community impacted by the fishery together with the intensity of the fishery. When data is available, fishing effort with towed gear can be used to calculate the area swept by the gear per $\mathrm{kg}$ of catch landed. If such data is available with high geographic resolution (e.g. from a VMS) the seafloor impact can be described more in detail, especially if the types of marine habitats impacted and their distribution is known (e.g. through marine geological maps).

\section{Target species}

For commercially fished species under quota limitation, scientific advice should be used to judge whether the stock is within safe biological limits or not as a qualitative description of the fishery impact (however not related to the functional unit). For species where there is no scientific advice a suggested indicator was:

(Predation+ Fishery)/Production

If this indicator is $>1$ the stock is decreasing, if $<1$ it is increasing. However, a problem is to find data on predation and production. An inferior alternative is to study figures of estimated stock size in relation to fishing mortality, adding some factor for natural mortality (mainly by predation), which is often estimated at $20 \%$.

\section{By-catch species and ecosystem effects}

The problem with assessing the impact of catching by-catch species is similar to the previous case with the target species, only that many by-catch species are not regulated by a quota system and knowledge about their stock dynamics is sometimes very limited. In times when the main target stocks are decreasing, increased fishing pressure is directed towards traditional by-catch species and increasing knowledge about these species is therefore very important. The group has decided that with present knowledge it is not possible to quantify these impacts at the moment and in seafood LCAs, they can therefore only be described qualitatively. 


\section{Discard}

We have made a division of discard of commercially utilised species and discard of other species. For the ones commercially utilised one would optimally like to know numbers of individuals discarded and weight of those individuals per $\mathrm{kg}$ of catch landed. The economic loss of discarding (often under-sized or damaged) individuals of commercial species can then be estimated by applying a growth model showing how much that fish or crayfish would have been worth if left to grow in the sea for a year or two. For species with a current low economic value (e.g. many invertebrates) number of individuals and weight per $\mathrm{kg}$ of landed catch would be optimal to know. However, this information is rarely available. Only when research programmes looking at discards exist or perhaps when very few vessels are included in the study, such detailed information can be obtained. Otherwise, only a qualitative description can be included e.g. on which species are typically caught and discarded.

\section{Anti-fouling}

Regarding anti-fouling, the procedure has typically been to calculate the quantity of toxic substance used per $\mathrm{kg}$ of landed catch, assuming a certain brand of paint is applied once a year etc. The LCA software often includes characterisation methods for Ecotoxicity or Aquatic toxicity and gives a numeric result. However, these impact indicators (e.g. for $\mathrm{Sn}$ and $\mathrm{Cu}$ ) are rarely calculated for marine ecosystems and may be misleading.

\section{Eutrophication}

The same argumentation as for characterisation of toxic emissions applies to eutrophying emissions. Impact indicators are developed for freshwater ecosystems where phosphourous is the limiting nutrient and hence weighted much higher than nitrogen. However, marine ecosystems are often nitrogen limited and nitrogen should thus be given greater importance in characterisation of eutrophying emissions. Another thought was that the release of eutrophying emissions to water and air does not cause as much eutrophication if done at high sea as if done in costal areas.

\subsection{Future outlook and need for further research}

Even though considerable progress has been made in the development of seafood LCA methodology in recent years, there is still a long way to go. We see increasing need for the kind of environmental information coming out of seafood LCAs, with growing consumers awareness and an increasing number of companies having an environmental management system. The need to be able to get this kind of information quicker and easier than today is also very clear. With more studies available it is becoming easier to benefit from data inventories and methodological approaches used in new studies. The type of network activity reported here speeds up this development by making communication between different groups efficient. Some ideas for the next steps to take are developing easy tools ("shortcuts") for small and medium-sized enterprises in the seafood sector for environmental management, including environmental assessment like 
LCA. Moreover, different management systems such as traceability, environmental management and LCA efforts should be integrated into a general company management system to benefit from each other and minimise the work needed. To do so, the similarities (and differences) between the different management systems need to be identified. Development of environmental indicators and bench-marking of important fisheries would be other ways for simplified assessment of the environmental performance of fisheries. An idea for an innovative and policy-oriented way of dealing with these issues is to develop future scenarios where seafood production is sustainable and from that point identify measures that have to be taken to reach the desired future situation. In conclusion, Environmental Assessment like LCA has shown to be a very useful tool both for companies, policy-makers and consumers. For seafood, methods are still under development but many ways to apply the knowledge and data from existing studies have been identified. Therefore Environmental Assessment of seafood will be an exiting research field in the years to come. 


\section{Network participants}

Harald Ellingsen

SINTEF Fisheries and Aquaculture

Trondheim, Norway

e-mail: harald.ellingsen@fish.sintef.no

Helga Eyjolfsdottir ${ }^{\star} / E v a$ Yngvadottir

Icelandic Fisheries Laboratories

Reykjavík, Iceland

e-mail: eva@rf.is

*present address: Environmental Regulation Division

Environment and Food Agency

Reykjavik, Iceland

e-mail: helgae@ust.is

Erling Larsen

Danish Institute for Fisheries Research

Lyngby, Denmark

e-mail: epl@dfu.min.dk

Staffan Larsson

National Board of Fisheries

Göteborg, Sweden

e-mail: staffan.larsson@fiskeriverket.se

Berit Mattsson

The Swedish Institute for Food and Biotechnology

Göteborg, Sweden

e-mail: bm@sik.se 
Thomas Ohlsson

The Swedish Institute for Food and Biotechnology

Göteborg, Sweden

e-mail: to@sik.se

Jyri Seppälä

Finnish Environment Institute

Helsinki, Finland

e-mail: jyri.seppala@vyh.fi

Frans Silvenius

Finnish Game and Fisheries Research Institute

Helsinki, Finland

e-mail: frans.silvenius@rktl.fi

Mikkel Thrane

Aalborg University

Aalborg, Denmark

e-mail: thrane@plan.auc.dk

Friederike Ziegler

The Swedish Institute for Food and Biotechnology

Göteborg, Sweden

e-mail: fz@sik.se 
Obtain your Nord and TemaNord reports from:

\author{
BELGIUM \& LUXEMBOURG \\ Jean de Lannoy \\ Avenue du Roi, 202, 1190 Brussels \\ Tel +32 (0)25385169 \\ Fax +32 (0)2538 0841 \\ jean.de.lannoy@euronet.be
}

\section{CANADA}

Renouf Publishing Company Ltd

5369 Canotek Road, Ottawa,

Ontario K1J 9J3

Tel + 1 (613) 7452665

$\mathrm{Fax}+1$ (613) 7457660

order.dept@renoufbooks.com

www.renoufbooks.com

\section{CHINA}

CNPIEC

Europe Division 16 Gongti East Road,

P.O. Box 88, Beijing

Tel +86105066 688-8

Fax +86 105063101

\section{DENMARK}

Svensk-Norsk Bogimport A/S

Esplanaden 8 B, 1263 København K

Tel +4533142666 Fax +4533143588

snb@bog.dk

www.snbog.dk

\section{ESTONIA}

Astro Raamatud AS

Pärnu mnt 142, 11317 Tallinn

Tel +372 6548485 Fax +3726548475

book@astro.ee

\section{FAROE ISLANDS}

H.N. Jacobsens Bókahandil

Postboks 55, 110 Tórshavn

Tel +298 311036 Fax +2983178 73

hnj@hnj.fo

www.hnj.fo

\section{FINLAND}

Akademiska Bokhandeln

PB 128, Centralgatan 1,

00101 Helsingfors

Tel +358 912141

akatilaus@akateeminen.com

www.akateeminen.com

\section{FRANCE}

Librairie LAVOISIER

14 , rue de Provigny,

94236 Cachan Cedex

Tel +33 (1) 47406700

Fax +33 (1) 47406702

group@lavoisier.fr

www.lavoisier.fr

\section{GERMANY}

UNO-Verlag GmbH

Am Hofgarten 10, 53113 Bonn

Tel +49 (0)228 949020

$\mathrm{Fax}+49$ (0)228 9490222

info@uno-verlag.de

www.uno-verlag.de

\section{HUNGARY}

Euro Info Service

PO Box 1039, 1245 Budapest

Tel +36 (1) 3292487

Fax +36 (1) 3492053

euroinfo@euroinfo.hu

\section{ICELAND}

Mál og Menning

Laugavegi 18, 101 Reykjavik

Tel +354 (9)5152500

Fax +354 (9)515 2505

books@penninn.is

\section{LATVIA}

Jana Rozes Gramàtnica

Kr. Barona iela 5, 1011 Riga

$\mathrm{Tel}+371(0) 2284288$

Fax +3717370922

\section{LITHUANIA}

Penki Kontinentai

A. Stulginskio 5, 2001 Vilnius

Tel +370 (5) 2664540

Fax +370 (5) 2664565

books@5ci.lt

www.books.lt

\section{NORWAY}

Akademika A/S

Postboks 84 Blindern, 0314 Oslo

Tel +4722853030 Fax +4722 853080

bloken@sio.uio.no

www.akademika.no

\section{ROMANIA}

Euromedia s.r.I.

Str Dionisie Lupu nr 65, 70184 Bucuresti

Tel + 4016140664

$\mathrm{Fax}+4013129646$

\section{SWEDEN}

Fritzes

Kundservice, 10647 Stockholm

Tel +46 (0)8 6909190

$\mathrm{Fax}+46(0) 86909191$

order.fritzes@nj.se

www.fritzes.se
THE NETHERLANDS

De Lindeboom Internationale Publicaties

M.A. de Ruyterstraat $20 \mathrm{~A}$,

NL-7482 BZ Haaksbergen

Tel +31 (0)53 5740004,

Fax +31 (0)53 5729296

books@delindeboom.com

www.delindeboom.com

\section{UNITED KINGDOM}

The Stationery Office

P.O. Box 276, London SW8 5DT

Tel +448706005522

Fax +44 8706005533

customer.services@tso.co.uk www.tso.co.uk/bookshop

USA

Bernan

4611-F Assembly Drive,

Lanham MD 20706-4391

Tel +1 (301) 4597666

Fax +1 (301) 4590056

query@bernan.com

www.bernan.com

\section{ÅLAND}

Lisco bok- och pappershandel

Skarpansvägen 25, Box 8 ,

22101 Mariehamn

Tel +358 (0)1817 177

Fax +358 (0)18 19771

info@lisco.fi 